\title{
Observed trends in Earth System behavior
}

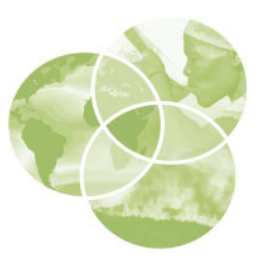

Will Steffen*

The behavior of the Earth System over the past two centuries has been dominated by the rapid rise of human activities as a significant geophysical force at the global scale. After the proximate and ultimate human drivers of change in the Earth System are described, the cumulative impact of these drivers on the structure and functioning of the Earth System are explored. Although the imprints of human activities are most profound on the land surface and in the atmosphere, significant effects are also discernible in the coastal seas, in the ocean, and-indirectly-in the cryosphere. The perturbations to the carbon cycle by human activities, most notably the burning of fossil fuels, is the most well-known example of change in global biogeochemical cycling over the past two centuries. However, human modification of the nitrogen cycle is arguably even more pervasive, and other biogeochemical cycles, such as the phosphorus and sulfur cycles, have also been significantly altered by human activities. The changes to the planet's biodiversity over the past two centuries have been profound and continue to accelerate; the Earth is now in the midst of its sixth great extinction event. All of these human-driven changes have implications for the climate system, and in turn are affected by changes in the physical climate. The concept of the Anthropocene-the proposal that the Earth has entered a new geological epoch-is a powerful way to understand the many interacting ways in which over six billion humans have collectively become a geophysical force that rivals the great forces of Nature and are now driving accelerating changes to the behavior of the Earth System. ๑ 2010 John Wiley \& Sons, Ltd. WIREs Clim Change $20101428-449$

$\mathrm{T}$ he recent phenomenon of anthropogenic climate change has focused attention on the global environment-how it normally behaves and the ways in which human activities are influencing its behavior. Two terms are have come into common use when discussing global environmental change: (1) the 'Earth System', which is defined in more detail in the next section; and 'functioning', which refers to the ways in which the Earth System transports and transforms material and energy, and in so doing creates an environment for biological species. The terms 'behavior' and 'functioning' will be used interchangeably in this review.

The behavior of the Earth System is constantly changing on a very large range of time scales, from millions of years to seconds and minutes. This review

*Correspondence to: will.steffen@anu.edu.au

Climate Change Institute, The Australian National University, Canberra, ACT 0200, Australia

DOI: $10.1002 /$ wcc. 36 focuses on the very recent past-only the last two centuries-up to the present. This is the period over which human activities have grown in magnitude to become major factors in the functioning of the Earth System. The Holocene epoch ${ }^{1}$ - the last 11,650 years during which agriculture and civilizations have developed-provides a baseline for analyzing the nature and importance of human-driven trends. More distant times in the past may be used as reference points when appropriate.

\section{THE EARTH AS A SYSTEM}

The term 'Earth System' is usually defined as the energy fluxes and set of interacting physical, chemical, and biological cycles that provide the conditions necessary to support life on the planet. ${ }^{2}$ The concept of the Earth System embodies several important features. First, the major external energy source for the Earth System is the sun, but the forcings and feedbacks within the System are as least as important as the 


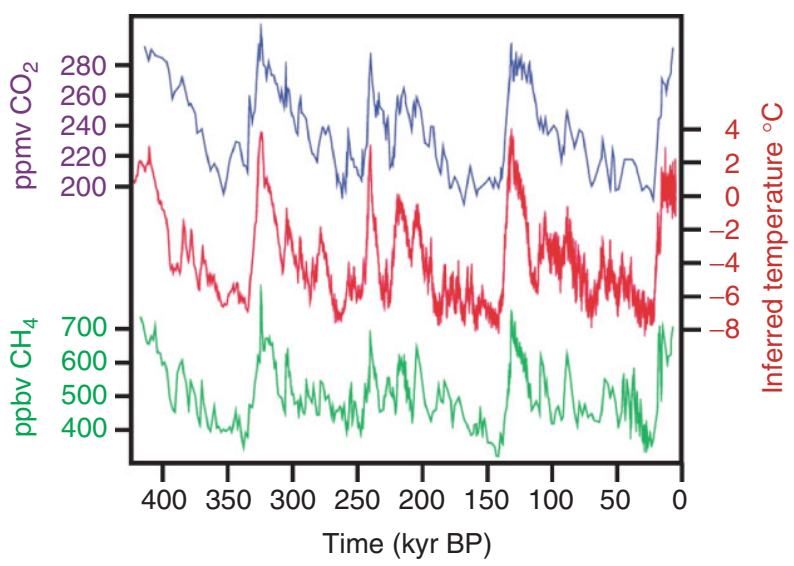

FI G URE 1 | The 420,000-year Vostok (Antarctica) ice core record showing the regular pattern of atmospheric $\mathrm{CO}_{2}$ and $\mathrm{CH}_{4}$ concentration and inferred temperature through four glacial-interglacial cycles (Adapted with permission from Ref 5. Copyright 1999 Nature).

external energy source in driving the functioning of the System and influencing the trends that are observed. Second, ecological processes are an integral part of the functioning of the Earth System, especially in terms of feedbacks; ecosystems are not simply the recipient of changes in the physico-chemical part of the System. Third, the functioning of the Earth System shows patterns and variability on many different time scales, from years and decades to centuries and millennia and even longer. The nature of the questions being asked or the problems addressed determine the time scale(s) of relevance.

Evidence for the functioning of Earth as a system, with emergent properties that are characteristic of the system as a whole, are shown clearly in ice core records from the polar ice sheets. The records from the EPICA ${ }^{3,4}$ and the Vostok ${ }^{5}$ ice cores in Antarctica demonstrate that the Earth operates as a single, interlinked, self-regulating system. Figure 1 shows records from the ice core of a proxy for temperature (red curve in middle), and for two of the carbonbased greenhouse gases-carbon dioxide $\left(\mathrm{CO}_{2}\right.$, purple curve) and methane $\left(\mathrm{CH}_{4}\right.$, green curve). The following features of the ice core record show characteristics typical of the systemic behavior of the Earth:

1. Taken together, the three records show a close coupling between climate and atmospheric composition, although it is not a simple cause-effect relationship but rather a linked set of forcing-feedback relationships that centrally involve biological processes. ${ }^{6}$

2. The records show a very regular pattern through time. The orbit of the Earth around the sun acts as the pacemaker for the ca. 100,000 year-cycles, but the smooth changes in the eccentricity of the Earth's orbit around the sun are not reflected in the saw-tooth pattern of observed change or in the magnitude of change between glacial and interglacial states. The internal dynamics of the Earth System-driven by the interaction among physical, chemical, and biological processes-dominate the magnitude and rate of observed changes.

3. The range over which temperature and gas concentrations vary between glacial and interglacial states is tightly constrained, and give rise to similar peak and minimum values for each cycle. The Earth System as a whole thus shows a high degree of self-regulation in terms of responding to an external forcing factor-the variation in incoming solar radiation.

A critical feature of the Earth System is that humans are fully a part of the system, interacting with biophysical processes in many different ways. Our role in Earth System functioning should therefore not be viewed as an outside force perturbing an otherwise 'natural' system, but rather as a fully coupled, integrated component of the Earth System. The role of human activities is particularly important in understanding the observed trends in Earth System behavior over the past 200 years.

\section{DRIVERS OF RECENT TRENDS IN EARTH SYSTEM BEHAVIOR}

The behavior of the Earth System is influenced by many factors, and it is often difficult to separate out driving processes and feedbacks in the functioning of a complex system. Nevertheless, a number of important geophysical processes can be identified as important natural drivers of Earth System behavior, while more recently human activities have become a significant geophysical force in the Earth's functioning (Figure 2).

\section{Natural Drivers}

There are many natural processes that drive change in Earth System behavior on geological time scales, including changes in plate tectonics, weathering processes that can change atmospheric composition, volcanic activity, and changes in the amount of incoming solar radiation. The last factor is particularly important, and is influenced by the orbit of the Earth around the sun as well as by changes in activity on the surface of the sun itself. In the time scale 


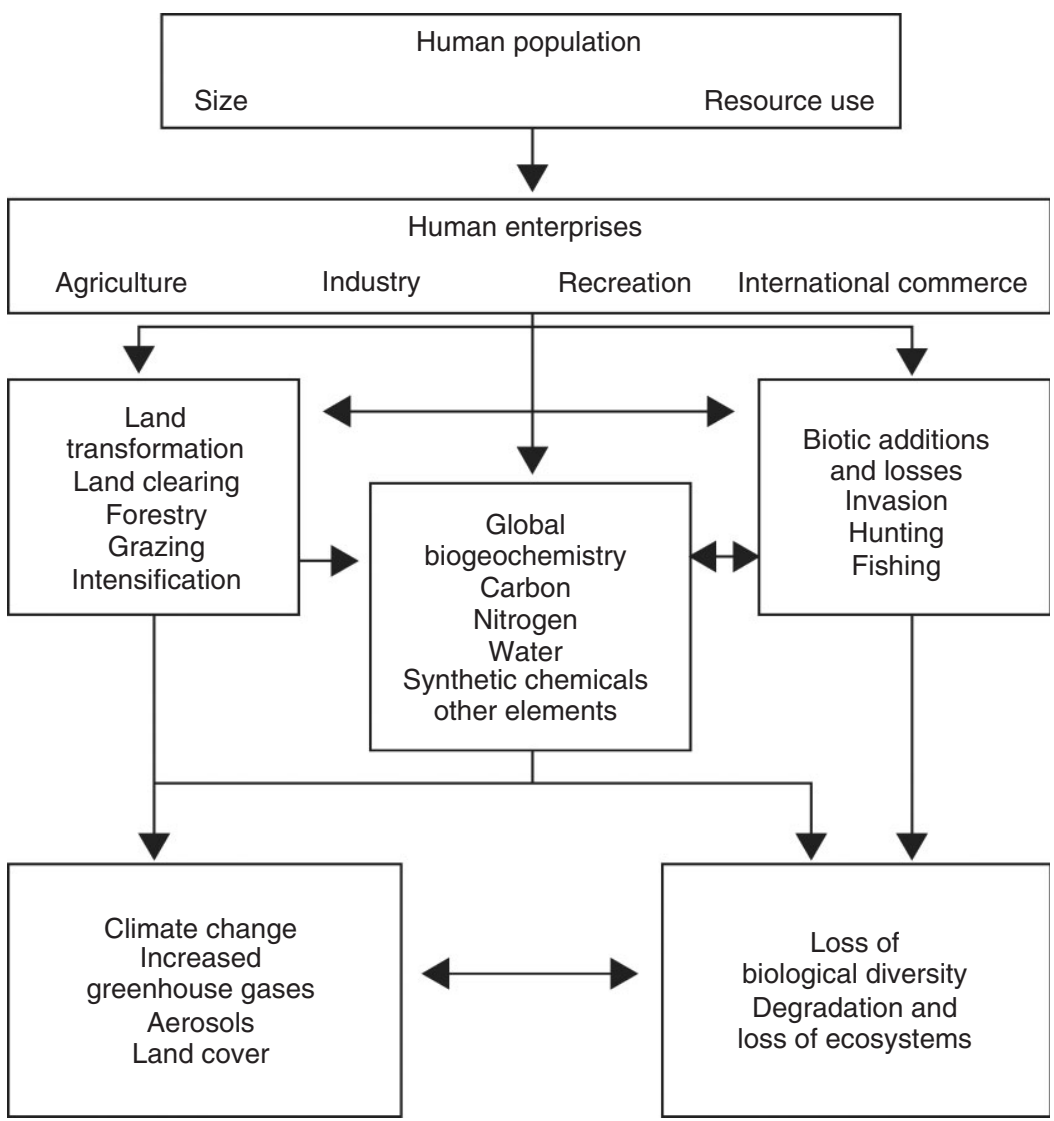

FIGURE 2 | The scope, degree, and interactive nature of human alteration of the Earth System (Adapted with permission from Ref 7. Copyright 1997 Science). of interest in this review-about 200 years-these geological processes can be assumed constant, apart from large volcanic eruptions, which can cool the climate for 2-3 years following the eruption, and changes in solar activity such as sunspots. However, over the past two centuries, these natural processes have been overwhelmed by the rapidly increasing effects of human activities on Earth System behavior, described in the next sections. For example, between 1750 and 2005 changes in solar irradiance increased radiative forcing at the Earth's surface by about $0.1 \mathrm{~W} / \mathrm{m}^{2}$ while the total net effect of human activities over the same period was to increase radiative forcing by about $1.6 \mathrm{~W} / \mathrm{m}^{2} .8$

\section{Proximate Human Drivers}

In earlier times, fishing, clearing land, and agricultural production were the dominant proximate human drivers of change in the functioning of the Earth System, but since the beginning of the Industrial Revolution, a number of processes associated with fossil fuel energy systems have become very important.

\section{Agriculture}

Over the past 200 years, the production of food has risen dramatically to keep pace with rising population.

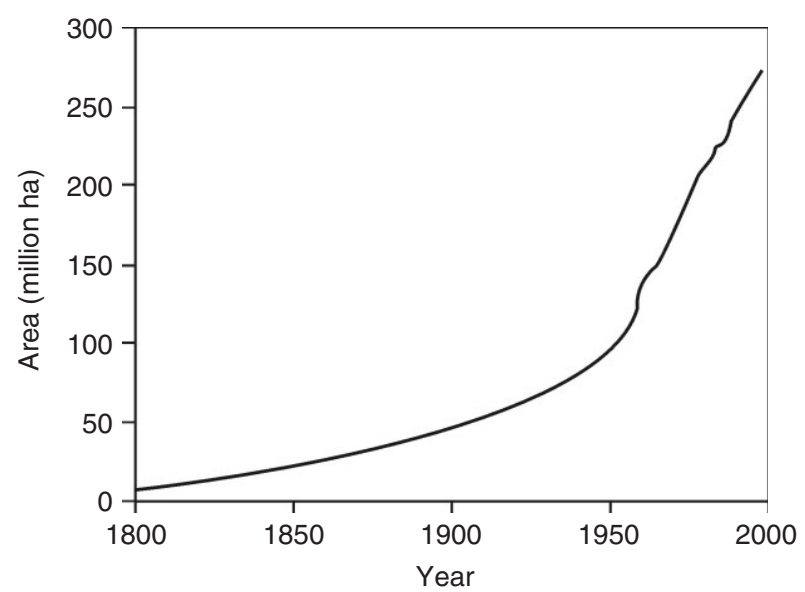

FIGURE 3 | World agricultural area under irrigation. ${ }^{11}$

The sharp increase in the land area under irrigation (Figure 3) is a good measure of this increase. For much of the period, expansion of agricultural land area was a major factor in increased production, but since 1950 the impressive gains in production have largely been due to intensification on existing agricultural land. In addition to irrigation, intensification has been driven by increased fertilizer and pesticide use., ${ }^{9,10}$ 


\section{Forestry}

The world's forests provide a wide range of products for humans-timber for construction, pulp for paper and packing, and fuel wood. Wood production has also increased through the last century but at a significantly lower rate than either grain or fish production. There are strong differences in consumption patterns between developed and developing countries, with nearly all fuel wood produced and consumed in the latter, whereas about $80 \%$ of industrial roundwood production occurs in developed countries. ${ }^{12,13}$ Plantations are becoming more important as a source of wood products; by 1995 they accounted for only $3 \%$ of forested land globally but produced $22 \%$ of the industrial roundwood supply. ${ }^{14}$

\section{Fishing}

On average about $16 \%$ of the protein consumed by humans comes from fish. ${ }^{15}$ As for grain production, the yield of the world's fisheries has risen dramatically in the past 50 years, from about 20 million tonnes in the mid-20th century to about 120 million tonnes by 2000. ${ }^{16}$ However, the catch from wild fisheries has leveled off over the past decade, and the proportion of fish consumed that is derived from aquaculture is rising steadily.

\section{Energy Production}

Energy production is the single most important proximate cause of anthropogenic climate change, largely through the rising emissions of carbon dioxide $\left(\mathrm{CO}_{2}\right)$ from the combustion of fossil fuels. Global energy production doubled over the past half-century, with much of it derived from fossil fuels. Although there is now concern about the longevity of oil reserves ${ }^{17}$ - the so-called 'peak oil' issue-there are still large reserves of coal so that a drop-off in oil consumption will not automatically solve the $\mathrm{CO}_{2}$ emission problem.

\section{Transport}

By the end of the 20th century, transport had grown to consume $25 \%$ of the world's energy supply and $50 \%$ of global oil production. With the number of motor vehicles expected to grow to 1000 million by $2025^{18}$ and aviation also growing rapidly, transport will likely consume a larger fraction of global energy in the coming decades.

\section{Industrial Production}

The production of the vast array of goods consumed by contemporary societies requires, in addition to large amounts of energy, a very large base of materials, including heavy metals, industrial chemicals, and construction materials. Industrial processes are the most common sources of both air and water pollutants, and a large range of other waste materials. Over 100,000 industrial chemicals are used by society, ${ }^{19}$ and although many of them are non-toxic, there is growing concern about the rapid rate of increase of chemical usage. From an Earth System perspective, some of these materials, such as heavy metals and some chlorinated organic compounds, are significant due to bio-accumulation through food chains and thus impact on the functioning of the biosphere.

\section{Ultimate Human Drivers}

The proximate drivers described above are those human activities most closely associated with observed trends in the functioning of the Earth System, but they are ultimately driven by the number of humans on Earth, their ability to consume goods and services, and the technologies used to produce these goods and services. This set of ultimate human drivers can be represented by the IPAT identity ${ }^{20,21}$ :

$$
I=P A T
$$

where $I$ is the environmental impact, $P$ the population, $A$ the affluence, and $T$ the technology. Although there is no doubt that population growth is a significant driver of human impacts on the global environment, since the Industrial Revolution—and particularly since the Second World War-the capability of individuals in the developed world to consume large quantities of materials and energy has become the dominant driver of environmental change. For example, a person living in a wealthy country on average consumes 2 times as much grain, 2 times as much fish, 3 times as much meat, 9 times as much paper, and 11 times as much liquid fuel as does a person living in a developing country. ${ }^{22}$

\section{A Systems Perspective on Human Drivers}

It is common to use a cause-effect or causal chain approach to link proximate and ultimate human drivers of change to their environmental impacts, but in reality impacts are often due to complex interactions between multiple drivers, involving institutions, values, markets, governance, and placebased contextual settings.

An excellent example of this complexity concerns tropical deforestation, one of the most prominent trends in Earth System structure over the last several decades. Tropical deforestation is often attributed to population pressure and poverty. However, a synthesis of a large number of case studies from the major 

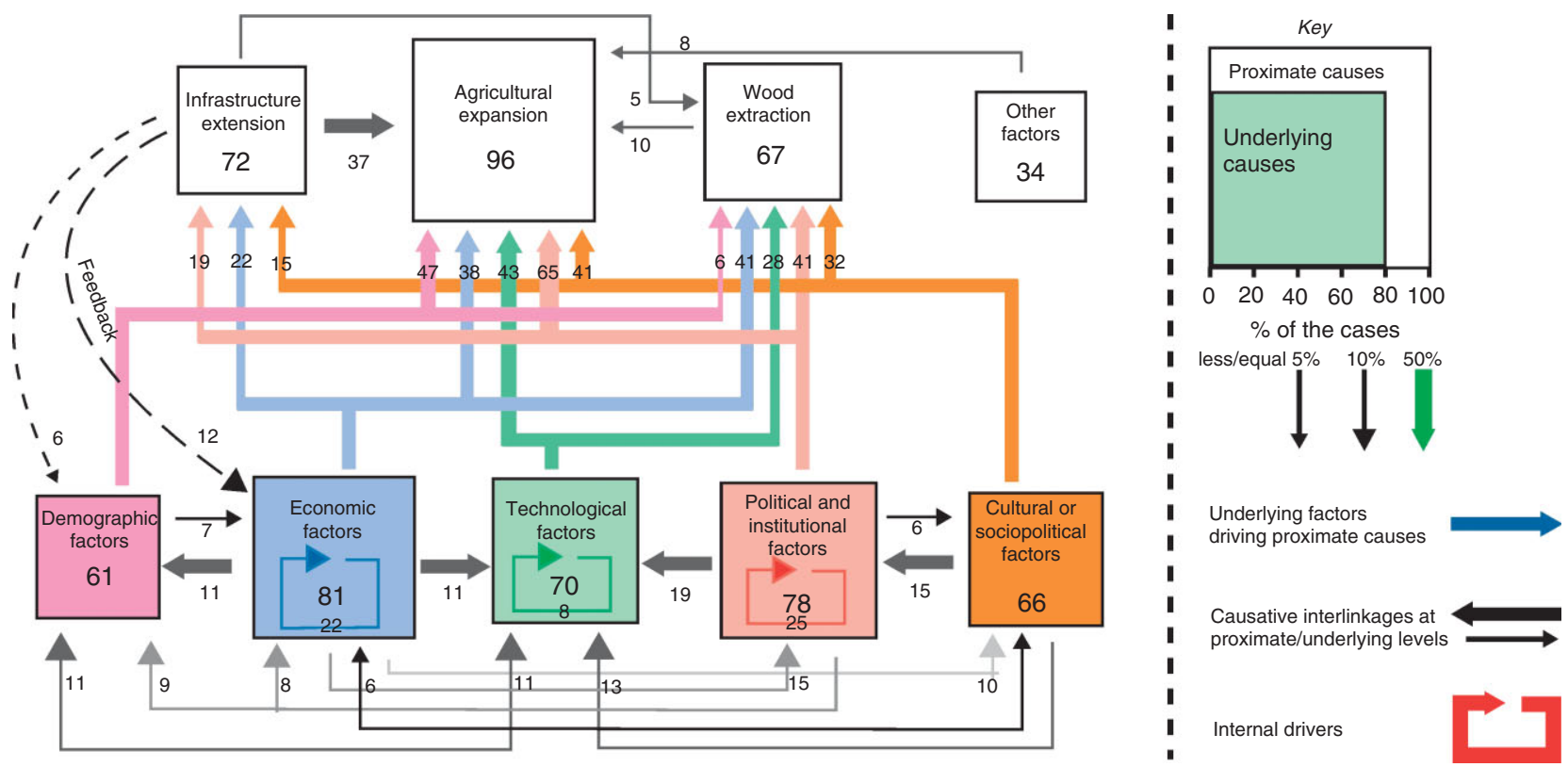

FIG URE 4 | The causative patterns of tropical deforestation from 1850 to 1997 based on a synthesis of 152 case studies that examined both proximate and underlying causes. $^{23}$

tropical forest regions of the world shows that this simple explanation is almost never correct. Rather, the patterns of land-use change in the tropics is usually driven by a complex array of factors, such as market and policy failures, terms of trade, debt and weak governance structures (Figure 4; Ref 23).

\section{HUMAN IMPRINT ON THE COMPARTMENTS OF THE EARTH SYSTEM}

\section{Land Cover and Land Use Change}

The trends in the land cover of the Earth over the past 200 years have been clearly dominated by human activities. Agriculture has been the largest driver of change, with much forested area and grasslands converted to croplands and pastures. Most studies of land-cover change suggest that about $50 \%$ of the total ice-free land surface has been converted or substantially modified by human action, ${ }^{6}$ with about $12 \%$ of the global land surface under cropland. ${ }^{24}$ Much of the remaining land is managed by humans in one way or another, even when something close to a natural vegetative cover remains.

Over recent decades, the global patterns of landcover change have been characterized by significant rates of clearing in the tropical forests ${ }^{25,26}$ and abandonment of agricultural land and subsequent reforestation in some parts of Europe and North

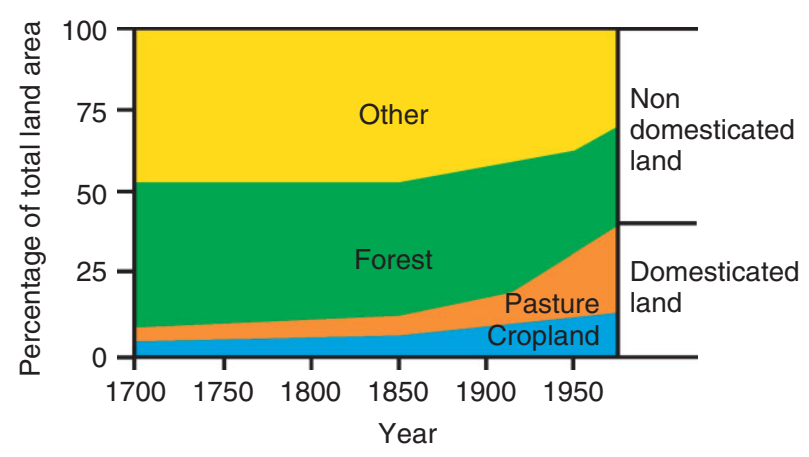

FIG URE 5 | Overview of human-driven changes in global land cover over the last 300 years. ${ }^{27}$

America. ${ }^{11}$ Overall, tropical deforestation dominates so that the global aggregate is still loss of forested land.

From the perspective of Earth System behavior, an appropriate way to summarize trends in the Earth's land cover is by the degree of 'domestication' of land by humans (Figure 5). By 1800, only about $10 \%$ of the land surface had been domesticated, leaving $90 \%$ in a natural state to play its role in Earth System functioning unaltered by human modification. By 1950, the proportion of domesticated land had risen to $25-30 \%$ and has continued to rise into the 21 st century.

A complementary approach to evaluating the effects of human activities on the terrestrial component of the Earth System is to estimate the amount 
of net primary production that is used, co-opted, or diverted by human activity from the pathway that it would otherwise have taken in the functioning of the Earth System. Net primary production is the net amount of carbon assimilated from the atmosphere by photosynthesis of terrestrial vegetation. Human use of net primary production is difficult to determine, and estimates range from 5 to $50 \% .{ }^{28-30}$ Whatever value is most accurate, it will surely imply a significant change in the role of the terrestrial surface in the Earth System as a result of human activities.

\section{Changes in Oceans and Coasts}

The most important trends in ocean behavior in the past 200 years are human-driven changes to biology and chemistry. Analogous to the human appropriation or diversion of net primary production in terrestrial ecosystems, one estimate suggests that humans are now harvesting about $8 \%$ of the primary production of the oceans. ${ }^{31}$ The estimates are much higher for the continental shelves and upwelling areas.

The most well-known human effect on the functioning of marine ecosystems is via fisheries, which remove much biomass at the top levels of marine food chains. It is now estimated that among fisheries for which information is available, $47-50 \%$ of fish stocks are fully exploited, $15-18 \%$ are overexploited, and $9-10 \%$ have been depleted or are recovering from depletion. ${ }^{16}$ The implications of these changes for the behavior of marine ecosystems are still largely unknown.

Human activities are also affecting the chemistry of the oceans via the rapidly rising concentrations of $\mathrm{CO}_{2}$ in the atmosphere. The increasing partial pressure of atmospheric $\mathrm{CO}_{2}$ leads to increasing dissolution of the gas in the surface waters of the ocean, forming carbonic acid. This process is slowly increasing the acidity of the ocean and decreasing the saturation state of calcium carbonate; the latter is important for marine organisms that form their shells from calcium carbonate (cf. WILEY article 2.2.1 'Ocean acidification').

Observations have shown that the global oceanic aragonite (a form of calcium carbonate) saturation ratio has already decreased from a pre-industrial value of 3.44 to a current value of 2.9 and is projected to decrease further to a value of 2.29 for a doubling of $\mathrm{CO}_{2} \cdot{ }^{32}$ Substantial changes in the composition and dynamics of marine biological communities will occur below aragonite saturation, ${ }^{33}$ with unknown but likely serious cascading effects up the food chain. Of the marine ecosystems that are sensitive to aragonite saturation state, coral reefs are the most intensively studied, and their prospects for surviving this century are not good if the concentration of atmospheric $\mathrm{CO}_{2}$ continues to rise unabated. ${ }^{34}$

The human imprint on the coastal zone is more pronounced than on the open ocean owing to the large human populations living on or near the coast and the extraction of resources from coastal seas. A systematic typology of the Earth's coastal zone stratified by the degree of human modification shows that there are no large stretches of coastline outside of Greenland, northern Canada and Siberia, and remote areas of Australia and South America that are without significant human influence. ${ }^{35}$

Just as for the land surface, the degree of direct human modification of the coastal zone can be estimated. For example, about $50 \%$ of mangrove forests have been converted to other uses, often to prawn farms. ${ }^{36,37}$ In general, about $29 \%$ of all coastal land (excluding Antarctica) has been altered or semialtered by human activities. ${ }^{38,39}$

\section{Trends in Atmospheric Composition}

With the prominence of climate change as a global environmental issue, the imprint of human activities on the composition of the atmosphere has now become a headline issue. Although much of the attention in public discourse has focused on human-driven emissions of greenhouse gases, human activities have affected the atmosphere in other ways. The most important of these are aerosols and photo-oxidants.

Aerosols-mixtures containing liquid and/or solid particles in a carrier gas (such as the atmosphere)-influence the behavior of the Earth System in several ways. They directly affect the energy balance at the Earth's surface, with most aerosols scattering incoming solar radiation and thus acting to cool the climate at the Earth's surface. But aerosols also have important indirect effects, acting as condensation nuclei that affect the amount and type of cloud cover as well as the amount and pattern of rainfall.

Human influences on three of the most important types of aerosols-sulfate particles, smoke, and mineral dust-are now comparable to natural patterns of variation at the global scale. The concentration of sulfate particles of human origin, which arise largely through the combustion of fossil fuels and through smelting, peaked in the 1960s and have shown a decreasing trend since then. ${ }^{6}$ The rapid rise of industrialization in Asia, however, has led to the rise of sulfate aerosols in that region. ${ }^{40}$ Globally, humaninduced emissions of oxidized sulfur compounds are still more than double the natural sources.

Smoke is, in fact, an aerosol composed of a wide range of partially burned organic particles. Fires are 
a natural part of the dynamics of many ecosystems, especially semi-arid savannas and boreal forests, and so smoke plumes were a prominent feature of the pre-human atmosphere. However, over the past 100-200 years, the level of biomass burning has risen by about $30-50 \%$ (Ref 41 ; see also WIRE article 2.2.2 'Wildfires and climate change'). Estimates of the effect of this increase on the concentration of the various particles that comprise smoke are very difficult to make, but the amount of soot in the atmosphere due to human activities may have risen by as much as 10 -fold over natural sources. ${ }^{42}$

The amount of mineral dust in the atmosphere varies widely naturally. ${ }^{5}$ However, owing to landuse/cover change, the amount of degraded land has increased over the past two centuries, increasing the area of dust sources. The amount of mineral dust in the atmosphere may have increased by $50-100 \%$ due to human activities. ${ }^{43}$

The release via human activities of oxidizing compounds like nitric oxide into the atmosphere has been a concern for decades in terms of urban air pollution-the formation of photochemical smog. At the scale of the Earth System as a whole, the effect of human activities on photo-oxidants is most pronounced via changes in the concentration of ozone. In the troposphere (lower atmosphere), where ozone is harmful to health and is a greenhouse gas, its concentration has been rising, an indirect effect of human-driven emissions of nitrogen oxides, hydrocarbons, and carbon monoxide. Long-term measurements of tropospheric ozone are few and scattered, but suggest that its concentration may have risen by as much as four-fold over the past century. ${ }^{44,45}$

The most well-known case of change in ozone concentration is in the stratosphere, where the emission of chlorofluorocarbons, which are man-made compounds, since the 1950s has led to a loss of stratospheric ozone, most pronounced over the South Pole. The peak loss of ozone there is up to $60 \%$ in the austral spring while much smaller but still measurable decreases in ozone have been observed over the mid-latitudes. ${ }^{46}$

Finally, the human-driven increase in the concentrations of greenhouse gases is now wellestablished through direct measurements in the atmosphere coupled with ice core records for earlier periods. Figure 6 shows the changes from 1700 to 2000 for the three most important greenhouse gases that are altered directly by human emissions- $\mathrm{CO}_{2}$, methane $\left(\mathrm{CH}_{4}\right)$, and nitrous oxide $\left(\mathrm{N}_{2} \mathrm{O}\right)$. The three show very similar patterns, with accelerating increases since the beginning of the Industrial Revolution; the concentration of all three are well above the envelope

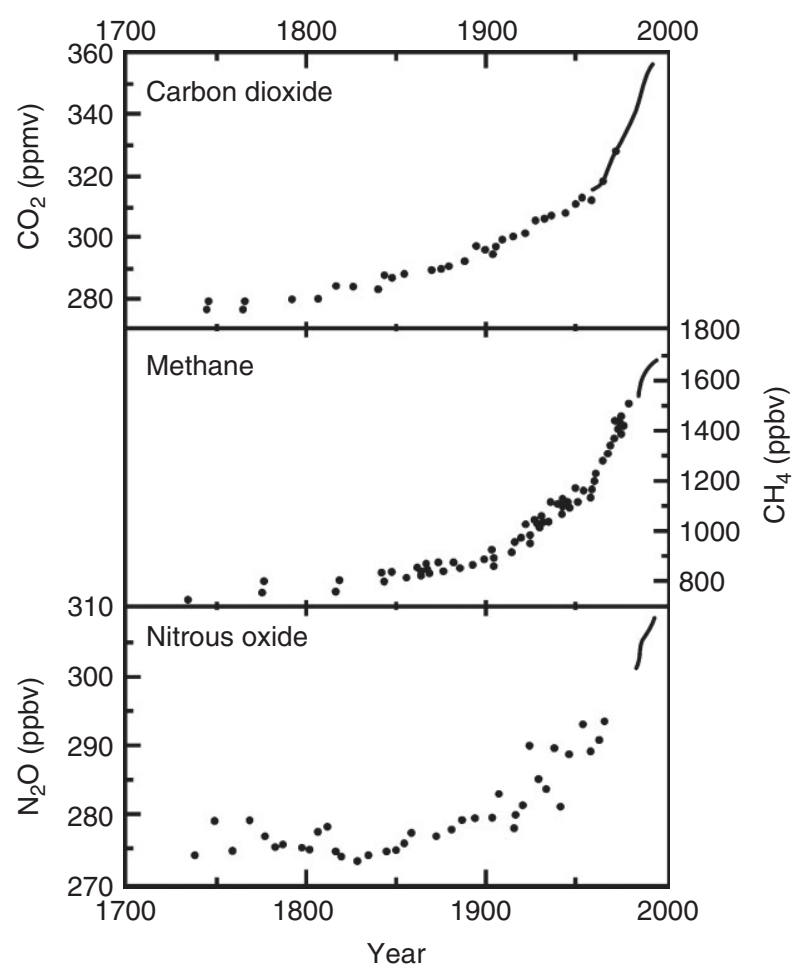

FIG URE 6 | Atmospheric changes in concentrations of (a) $\mathrm{CO}_{2}{ }^{47}$; (b) $\mathrm{CH}_{4}{ }^{48,49}$; and (c) $\mathrm{N}_{2} \mathrm{O}^{50}$ over the last 300 years, as reconstructed from Greenland and Antarctic ice core studies. ${ }^{41}$

of natural variability through the late Quaternary as recorded in the ice cores (e.g., Ref 5 for $\mathrm{CO}_{2}$ and $\mathrm{CH}_{4}$ ).

\section{Changes in the Cryosphere}

The cryosphere-frozen water as snow, sea ice, landbased glaciers and ice sheets, and frozen soilwater (permafrost) - plays an important role in Earth System behavior, primarily through the reflection of a large fraction of incoming solar radiation back away from the Earth's surface. Human activities have a negligible direct effect on the cryosphere, but through humaninduced climate change, significant changes in the cryosphere have begun to be observed over the last two centuries. The two most well-documented are seasonal snow cover and Arctic sea ice.

Forty-year (1966-2005) satellite records of snow cover have confirmed a decrease in all months in the Northern Hemisphere except for November and December. In particular, the snow cover has decreased in spring. There appears to have been a stepwise drop in annual mean snow cover of $5 \%$ in the late $1980 \mathrm{~s}^{8}$

Permafrost is changing in most areas of the Northern Hemisphere in ways consistent with the strong warming in that region. The maximum depth of seasonal permafrost has decreased by about 
$0.3 \mathrm{~m}$ in Eurasia over the past half-century, and the maximum seasonal thaw depth (the active layer) has increased by about $0.2 \mathrm{~m}$ in the Russian Arctic over a similar period. The maximum area of seasonally frozen ground decreased by $7 \%$ over the Northern Hemisphere since about 1950, with a decrease of $15 \%$ in spring. ${ }^{8}$

The area of Arctic sea ice (the layer of ice floating on the surface of the water) has diminished by about $2.5 \%$ per decade since 1978 with the rate of ice loss increasing over recent years. Sea ice around Antarctica shows a high degree of interannual variability over the same period but no definite trend. In fact, there has been a slight, but not statistically significant, increase in Antarctic sea ice extent over the past 15 years. ${ }^{42}$ Changes in sea ice extent are important for Earth System behavior because they help to modulate the surface radiation balance in the polar regions.

A potentially major change in the cryosphere would be the loss of significant amounts of ice from the large polar ice sheets on Greenland and Antarctica. There is enough ice on these two land-based ice sheets to raise sea level by 7 and $57 \mathrm{~m}$, respectively. The trends for both ice sheets are complex, with some areas of accretion of ice in the interior due to enhanced snowfalls but areas of shrinkage around the edges (Figure 7). Overall, there has been no discernible trend in the mass of the Antarctic ice sheets but the Greenland ice sheets appear to be losing mass at a rate of 50-100 Gt/year over the last decade or so. ${ }^{42}$ Recent observations show an acceleration of the loss of ice mass from Greenland ${ }^{51}$ and a net loss of ice from the West Antarctic Ice Sheet. ${ }^{52}$

\section{HUMAN IMPRINT ON BIOGEOCHEMICAL CYCLES OF THE EARTH SYSTEM}

The previous section summarized human modification of several of the major compartments of the Earth System. These changes are important in their own right, but become even more important in the context of the major cycles of material and energy that largely control the behavior of the Earth System at the global scale. As for the compartments, the imprint of human activities on global biogeochemical cycling are now beyond doubt and, in many ways, has become the dominant driver of observed trends over the past two centuries.

\section{Hydrological Cycle}

In terms of vertical water vapor flows from the land surface to the atmosphere, the net effect of human activities has been very small. The reduction of water vapor flows from the conversion of forests to other land-cover types, primarily croplands and grasslands, has been almost exactly compensated by the increased evaporation from excess liquid water impounded behind dams or extracted from below ground, primarily for irrigation. ${ }^{54}$

In terms of flows of liquid freshwater, humans have a profound influence, particularly by the interception and storage of water. There are over 45,000 dams of $15 \mathrm{~m}$ or higher around the world; about $16,000 \mathrm{~km}^{3}$ / year of flow is intercepted by these dams. This amounts to about $40 \%$ of the total global runoff to the oceans. ${ }^{54}$ In the Northern Hemisphere, about $23 \%$ of the flow in the 139 largest rivers is not affected by impoundments. ${ }^{55}$ The extraction of water resources has become so intense in some parts of the world that about $25 \%$ of the world's river systems run dry before reaching the ocean. ${ }^{56}$

Another way to quantify the human influence on the flow of water between land and ocean is to estimate the aging, or change in residence time, of river water at the mouth of the major rivers of the world (Figure 8). Residence times vary greatly depending on the river system and the nature of the impoundments on it, but a global average is now around 4 months, compared with an average residence time of 2 weeks for unimpeded flow. In some river systems (e.g., the Colorado River in North America), the average residence time is about 1 year. ${ }^{54}$

One of the most important implications of the longer residence times in river systems is to trap a substantial proportion of the suspended sediments in the river and also to modify water chemistry. It has been estimated that the world's largest reservoirs trap about $30 \%$ of the sediment flux that would otherwise have reached the ocean. ${ }^{54}$

A growing human perturbation to the hydrological cycle is the extraction of groundwater at rates higher than the recharge flows, leading to eventual depletion of the resource as well as associated effects such as land subsidence and saltwater intrusion in coastal areas. There are now several well-known global examples, such as the Ogallala aquifer in the central United States and the Chad Basin in Nigeria, where extraction of water is clearly at unsustainable levels and water levels are dropping substantially. ${ }^{6}$ There is not yet, however, a good global estimate of total groundwater resources and their use by humans.

\section{Carbon Cycle}

The behavior of the carbon cycle has been substantially modified by human action over the past two 


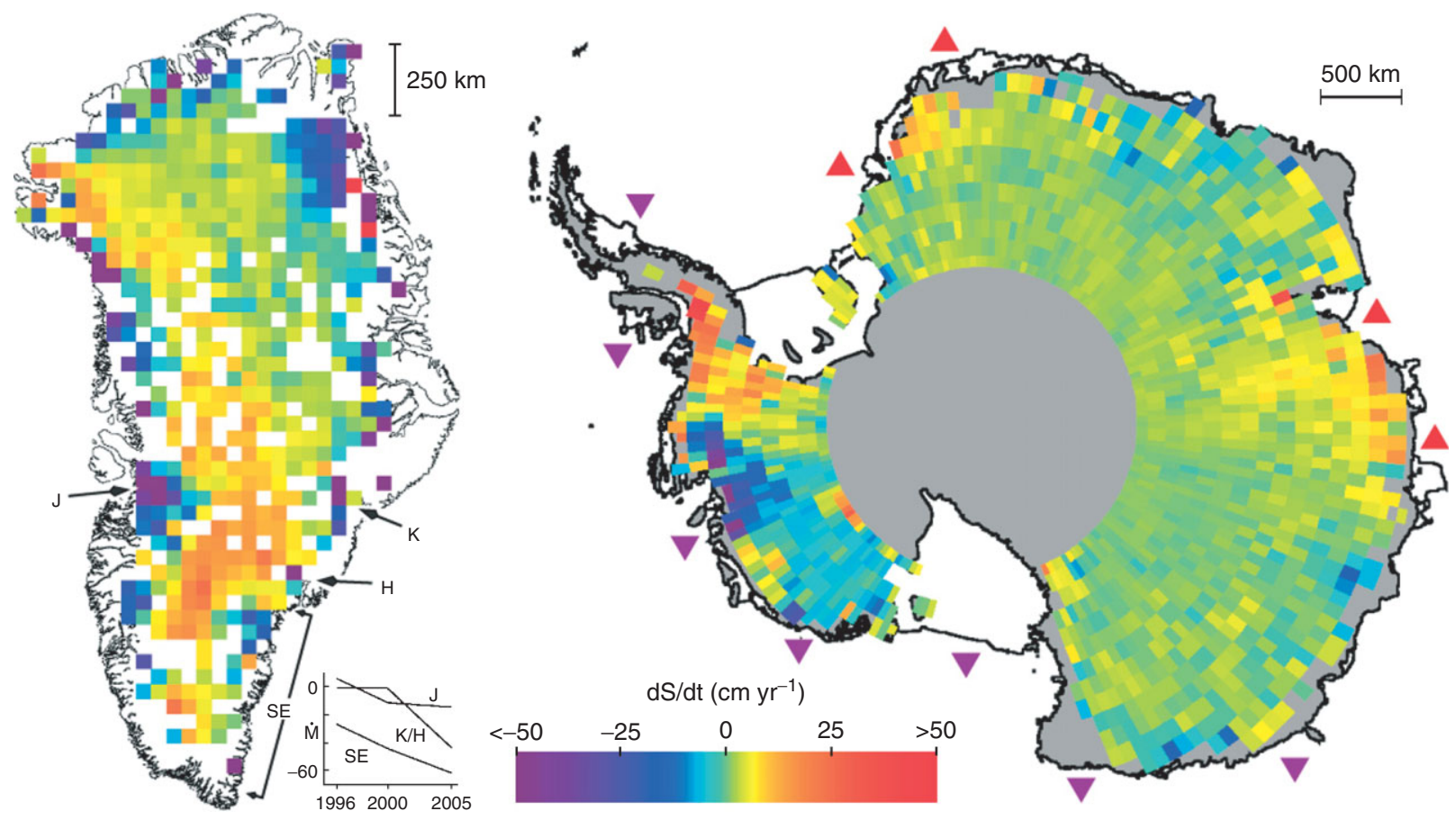

FIG URE 7 | Rates of observed surface elevation change for Greenland (left, 1989-2005) and Antarctica (right, 1992-2005). Red colors indicate a rise in elevation, which generally mean an increase in ice mass, whereas blue colors indicate a drop in elevation and a loss of ice mass. The letters along the Greenland coast refer to outlet glaciers and the small inset shows their change in mass balance with time. For Antarctica, the triangles along the coast show trends in ice shelves; purple triangles show thinning of ice, and red triangles show thickening of ice (Reprinted with permission from Ref 8. Copyright 2007 Cambridge University Press).

centuries, a trend that has gained much attention because of its role in influencing climate. When considering the gross fluxes of carbon between the atmosphere and the ocean and land, it might seem that human perturbations to these fluxes are negligible. The atmosphere and land exchange about $120 \mathrm{Pg}$ $\mathrm{C} /$ year and the atmosphere and ocean about $90 \mathrm{Pg}$ C/year (based on data from Ref 58). By comparison, human emissions of carbon are now about $10 \mathrm{Pg}$ C/year, less than $5 \%$ of the total annual exchange between the Earth's surface and the atmosphere.
The natural fluxes of carbon among the Earth System compartments are two-directional, and are very nearly in balance on an annual basis. From this perspective, as shown in Figure 9, the humandriven fluxes become very significant. ${ }^{59}$ Humandriven emissions of $\mathrm{CO}_{2}$ are composed largely of (1) emissions from fossil fuel combustion, which have grown strongly especially since 1950 and now dominate the emissions budget and (2) emissions associated with deforestation and conversion of those lands to cropping or grassland. Until about 1950,

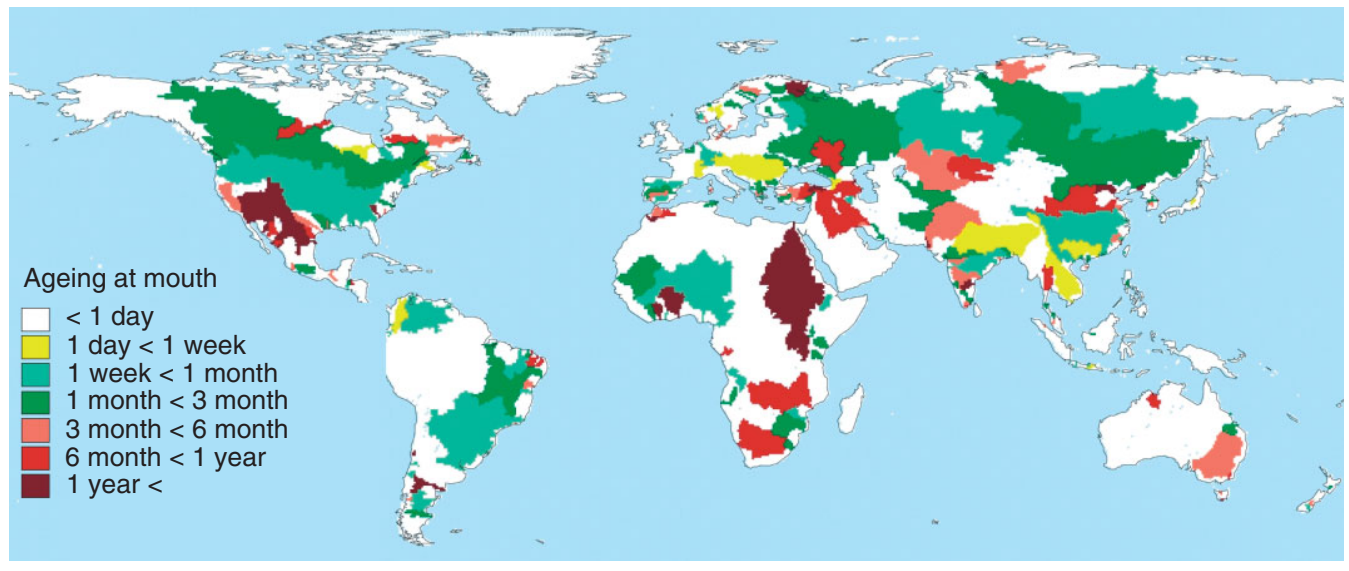

FIGURE 8 | Aging of river water, as computed at the mouth of each of the 236 regulated drainage basins.${ }^{57}$ Aging varies due to river regulations on the reservoirs. 


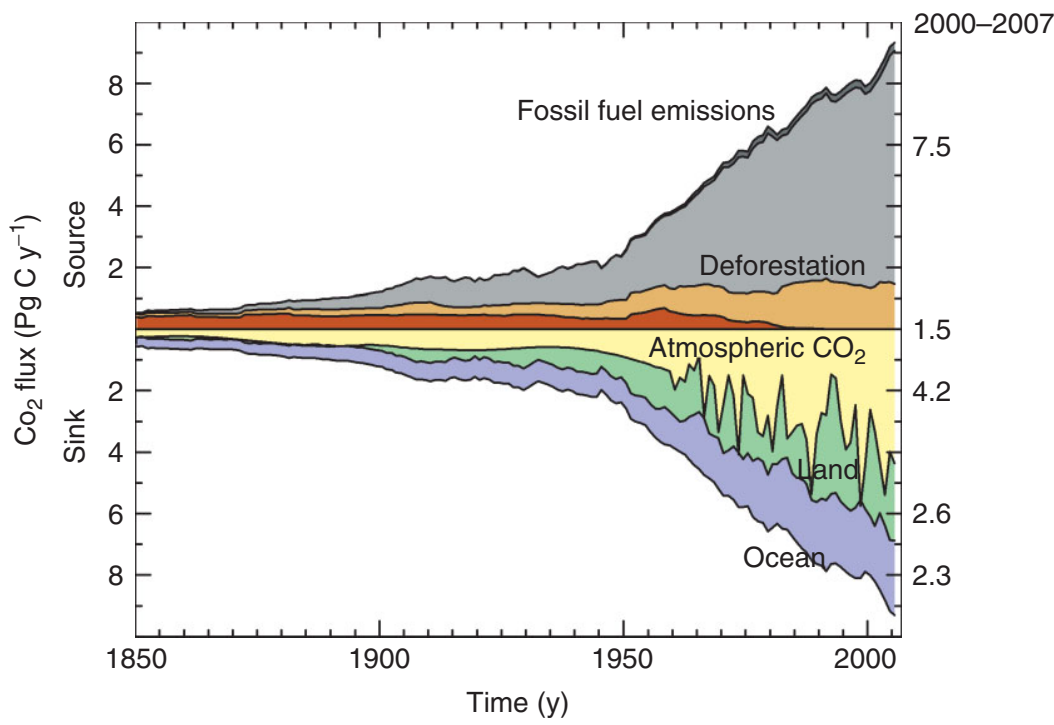

FIG URE 9 | The global carbon budget from 1850 to 2007. (Data are from Refs 59,60).

the conversion of temperate forests, primarily in Europe and North America, has dominated emissions from land-cover change, but for the last-half century tropical deforestation has dominated emissions from land-cover change. In fact, over the past few decades, reforestation in some parts of North America and Europe $^{21}$ has meant that these areas have become net sinks of carbon from the atmosphere.

The nature of the two dominant, human-driven sources of carbon are fundamentally different with respect to the functioning of the global carbon cycle. Emissions associated with land-use change are part of the active biophysical cycling of carbon among land, ocean, and atmosphere. This is a fast cycle from a geological perspective, and so these sources can be reversed relatively quickly (as they are now in temperate forest zones). Fossil carbon, however, has been locked away from the active biophysical carbon cycle in chemically reduced forms for tens of millions of years. Mining fossil carbon, oxidizing (burning) it, and then releasing the oxidized product to the atmosphere represent a fundamental perturbation to the global carbon cycle, and have important implications for mitigation activities. In particular, using land-based approaches to sequester carbon (e.g., planting trees) can never be a long-term offset for fossil fuel-based emissions; it can only buy time until fossil fuel-based emissions can be reduced and eliminated, and until the ocean (the ultimate sink for atmospheric $\mathrm{CO}_{2}$ ) can absorb the $\mathrm{CO}_{2}$ that has already been emitted.

An obvious feature of recent trends in the global carbon cycle (cf. Figure 9) is that slightly less than half of human emissions of $\mathrm{CO}_{2}$ remains in the atmosphere; the rest is absorbed in roughly equal proportions by the land and the ocean. Both sinks have been growing in magnitude over the past half-century, roughly in proportion to the growing human emissions of $\mathrm{CO}_{2}$. The land sink shows considerable interannual variability over this period, but as a proportion of human emissions it has remained steady at about $28 \%$. The ocean sink, on the other hand, has shown a significant downward trend over the period, from about $32 \%$ of human emissions in 1960 to about $26 \%$ now. ${ }^{61}$

Much research over the past decade or so has focused on the possible behavior of the global carbon cycle through the rest of the century. The humandriven component of the carbon cycle cannot be predicted with any degree of confidence, but rather is treated as a suite of scenarios, or possible future trajectories. ${ }^{62}$ These range from a so-called businessas-usual trajectory, in which emissions continue to rise unchecked through the century, to scenarios where emissions peak within the next 10-20 years and then decline sharply. Some attempts have been made to simulate the behavior of the carbon cycle into the future, taking into account a rising global temperature. ${ }^{63}$ There is much variation in these projections, but all of them show that the current ocean and land sinks weaken as a proportion of human emissions. In addition, currently inert pools of carbon in the Earth System could become active and release carbon to the atmosphere if warming is sufficiently rapid or severe. An example of such a pool is the carbon stored in frozen soil (permafrost) in the northern high latitudes. The amount of carbon in permafrost is estimated to total twice the amount currently stored in the atmosphere ${ }^{64}$; this carbon is potentially vulnerable to the rates of climate change projected for the 21 st century. ${ }^{65}$ 


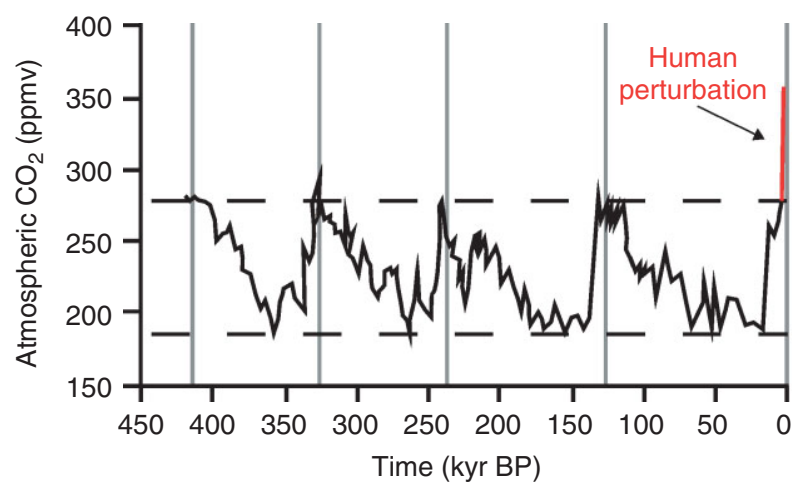

FIGURE 10 | Atmospheric $\mathrm{CO}_{2}$ concentration over the past 420,000 years from the Vostok ice core with the recent human perturbation superimposed. ${ }^{5,67}$

Figure 10 puts the recent human modification of the global carbon cycle into a long-term perspective by comparing it to the ice core record over the past 420,000 years. ${ }^{5}$ Through the late Quaternary, the variation in atmospheric $\mathrm{CO}_{2}$ concentration, a good indicator for the cycling of carbon among the atmosphere, land, and ocean, shows a regular ca. 100,000 -year cycle that is tightly coupled to the temperature record. A remarkable feature of this longterm record is that the concentration of $\mathrm{CO}_{2}$ is tightly constrained, never dropping much below $180 \mathrm{ppm}$ during ice ages and never rising much about 280 or $300 \mathrm{ppm}$ during the shorter interglacial periods. The human-driven changes to the global carbon cycle over the past two centuries stand out clearly against the long-term pattern of natural variability.
The current atmospheric $\mathrm{CO}_{2}$ concentration-about $385 \mathrm{ppm}$-represents a doubling of the 'natural operating range' of $\mathrm{CO}_{2}$. Although difficult to quantify from Figure 10, the rate at which this additional $\mathrm{CO}_{2}$ has been added to the atmosphere is about 10 or possibly 100 times greater than the natural rise or fall of atmospheric $\mathrm{CO}_{2}$ concentration during the ice core record. ${ }^{66}$

\section{Nitrogen Cycle}

By many measures, human modification of the nitrogen cycle is even more profound than the human-driven changes to the carbon cycle. Figure 11 compares the global terrestrial nitrogen budget in 1890 , before there was significant human influence on nitrogen stocks and flows, to the budget in 1990. The width of the arrows in Figure 11 is scaled to the magnitude of the flows.

The nitrogen cycle is obviously complex, but it can be simplified considerably in a conceptual sense by an initial focus on the flux of initially unreactive nitrogen, $\mathrm{N}_{2}$, in the atmosphere to the Earth's surface, where it is converted into reactive forms. This flux, which for the terrestrial part of the unperturbed cycle is about $100 \mathrm{Tg}$ N/year (and a similar amount is fixed by marine biota), makes reactive nitrogen available to the biosphere to support productivity of terrestrial vegetation, and, from an anthropogenic perspective, provides the 'available (reactive) nitrogen' needed for the production of food to support the human population. The $\mathrm{N}_{2}$ 'fixed' by the terrestrial biosphere then moves through the Earth System via multiple
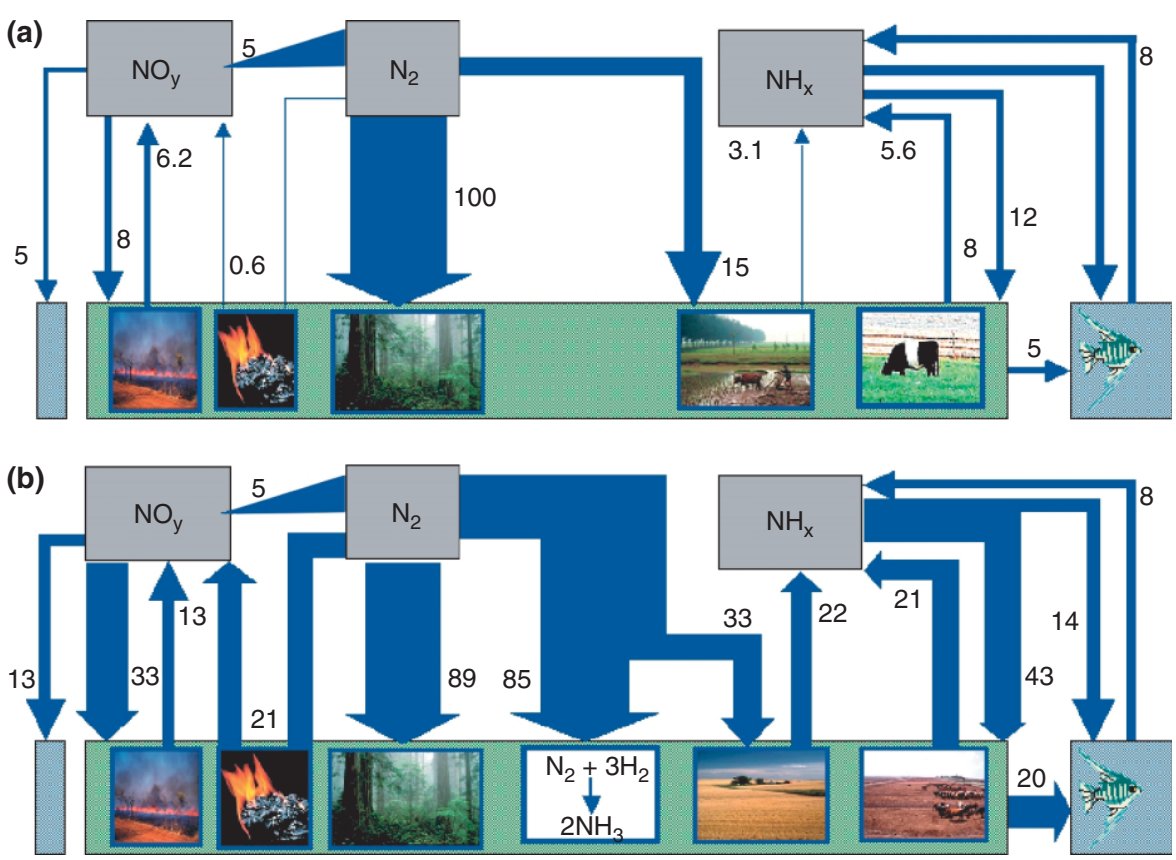

FIGURE 11 | Global terrestrial nitrogen budget for (a) 1890 and (b) 1990 in $\mathrm{Tg} \mathrm{N} / \mathrm{year}$. The emissions to the $\mathrm{NO}_{y}$ box from the coal represent fossil fuel combustion. Those from the vegetation include agricultural and natural soil emissions and combustion of biofuel, biomass (savanna and forests), and agricultural waste. The emissions to the $\mathrm{NH}_{x}$ box from the agricultural field include emissions from agricultural land and combustion of biofuel, biomass (savanna and forests), and agricultural waste. The $\mathrm{NH}_{x}$ emissions from the cow and feedlot reflect emissions from animal waste. The transfers to the fish box represent the lateral flow of dissolved inorganic nitrogen from terrestrial systems to the coastal seas (based on Ref 68). 
pathways and in both oxidized and reduced forms of nitrogen.

Over the past century, human modification of the nitrogen cycle has been extensive. ${ }^{68,69}$ Human activities now fix more $\mathrm{N}_{2}$ from the atmosphere into reactive forms than all terrestrial processes combined. This human-driven conversion of $\mathrm{N}_{2}$ occurs primarily through four processes: industrial fixation of atmospheric nitrogen to ammonia (80 Tg N/year); cultivation of leguminous crops $(40 \mathrm{Tg} / \mathrm{N})$; the combustion of fossil fuel $(20 \mathrm{Tg} / \mathrm{N})$; and biomass burning $(10 \mathrm{Tg} / \mathrm{N})$. Most of this new reactive nitrogen is intended to increase food production via fertilization, but there is much leakage to the environment-via emissions of $\mathrm{N}$-gases to the atmosphere, accumulation in the terrestrial biosphere, and pollution of rivers, lakes, wetlands, and the coastal zone.

The width of the arrows in Figure 11(b) indicates the magnitude of the human perturbation of reactive nitrogen flows through the Earth System. A quick visual comparison of the magnitude of the flows of nitrogen (width of the arrows) in Figure 11(a) and (b) demonstrates the pervasive influence of human modifications throughout the entire terrestrial nitrogen cycle. In quantitative terms, emissions of reactive nitrogen compounds to the atmosphere, for example, have increased from 29 to $107 \mathrm{Tg} \mathrm{N} /$ year, and transport of $\mathrm{N}$ from land to sea via rivers has increased by about $40 \mathrm{Tg}$ N/year. ${ }^{68}$ Ultimately, however, these fluxes are largely controlled by one giant 'valve'-the industrial fixation of atmospheric nitrogen for fertilizers.

Figure 12 shows in more detail the human modification of reactive nitrogen from terrestrial ecosystems through the coastal zone to the continental seas. Already by 1950, the flux of nitrogen through coastal zone had increased 10 -fold over 1800 values, ${ }^{70}$ but after 1950 an acceleration of the flow was noticeable. Model-based projections of future flows show further increases, linked closely with the need for food production to keep pace with an expanding human population over the next few decades.

This discussion has focused strongly on the terrestrial nitrogen cycle. Much less is known about the human perturbation of the marine nitrogen cycle, and the implications for stocks and flows of nitrogen in the ocean.

\section{Other Biogeochemical Cycles}

The trends in the behavior of other biogeochemical cycles also show the influence of human activity. For example, human mining of phosphorus activates about $12.5 \mathrm{Tg} \mathrm{P} / \mathrm{year}$, primarily for use in fertilizers or detergents. ${ }^{71}$ Natural weathering and root activity together activate about $2.2 \mathrm{Tg} \mathrm{P} /$ year. $^{72}$ As for nitrogen, much of this additional phosphorus is eventually released to the environment, where it is stored in terrestrial ecosystems or transported to the ocean. The phosphorus cycle does not have a significant atmospheric component.

As for phosphorus, the trends in the behavior of the sulfur cycle over the past two centuries are dominated by new human fluxes. The primary anthropogenic flux is via the combustion of fossil fuels, which releases an estimated $80 \mathrm{Tg}$ S/year to the atmosphere, compared with the corresponding

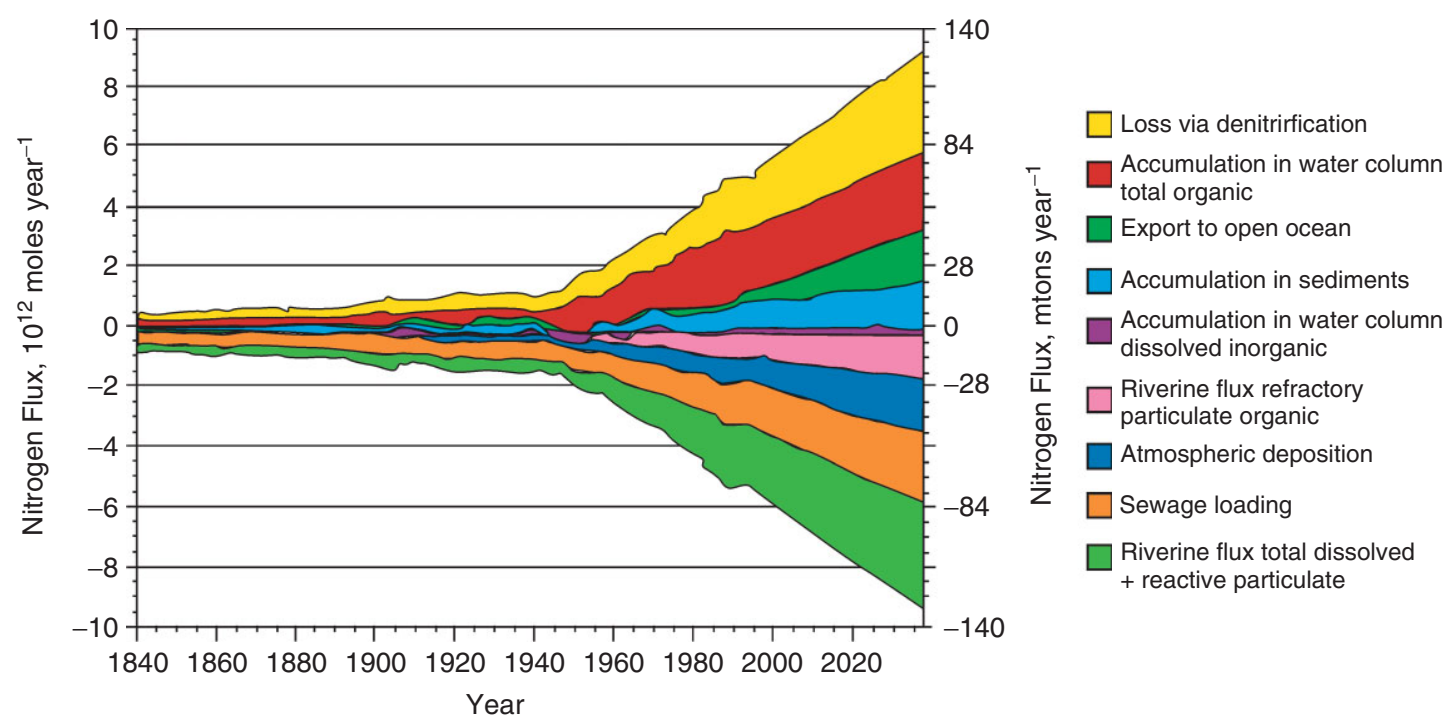

FIGURE 12 | Model-calculated partitioning of the human-induced nitrogen perturbation fluxes in the global coastal margin for the period since 1850 to the present (2000) and projected to 2035 under a business-as-usual scenario. ${ }^{70}$ 
natural flux of about $25 \mathrm{Tg}$ S/year. ${ }^{73}$ The sulfur dioxide formed by fossil fuel combustion is rapidly converted to sulfate ions and then to sulfuric acid, remains in the atmosphere for only days or a few weeks at most, and is returned to the Earth's surface via dry deposition or in rainfall.

\section{TRENDS IN EARTH'S BIOLOGICAL DIVERSITY}

As for many other aspects of Earth System structure and functioning, the human imprint on biological diversity is clearly visible above the trends driven by natural variability. Extinction of existing species and evolution of new species is a natural dynamic of the Earth System. The average rate of extinctions as discerned from the fossil record is in the range 0.1-1.0 extinctions per million species per year (E/MSY), with a median rate for mammals estimated at 0.3 E/MSY. ${ }^{74,75}$ The global extinction rate has likely increased 100-fold during the 20th century, with projections suggesting a further 100 -fold increase in extinctions by the end of this century, bringing the overall rate of species loss to 1000-10,000 E/MSY ${ }^{76}$ (Figure 13). These extinction rates constitute the sixth great extinction event in the history of the Earth, but the first to be driven by activities of a biological species. ${ }^{77}$
There are other ways to measure contemporary trends in biological diversity. A Living Plant Index has been developed by the Worldwide Fund for Nature (WWF) to track these trends by monitoring 1100 freshwater, marine, and terrestrial species as indicators. The Index has declined by $30-50 \%$ over the past 30 years alone. ${ }^{78}$

Extinction rates are a useful global indicator of biodiversity trends, but they can mask more subtle trends that have important implications for the functioning of the Earth System. Many species, while not yet extinct, have suffered massive range contractions so that the populations are small and fragmented. For example, many of Australia's unique marsupial mammals now occupy less than $20 \%$ of their original ranges, with several occupying less than $1 \%$ and are on the verge of collapse. ${ }^{79}$

Globally, the case of primates illustrates these more subtle trends. ${ }^{6}$ None of the 240 known primates has become extinct yet, so superficially there appears to have been no significant change. Yet 19 species of primates are now critically endangered and near extinction, 46 are endangered, and 51 are vulnerable; thus, about half of all primates are in decline and in danger of becoming extinct this century if present trends continue. Humans are now by far the most numerous of the 240 primate species, and the imbalance is growing at an astounding pace. The

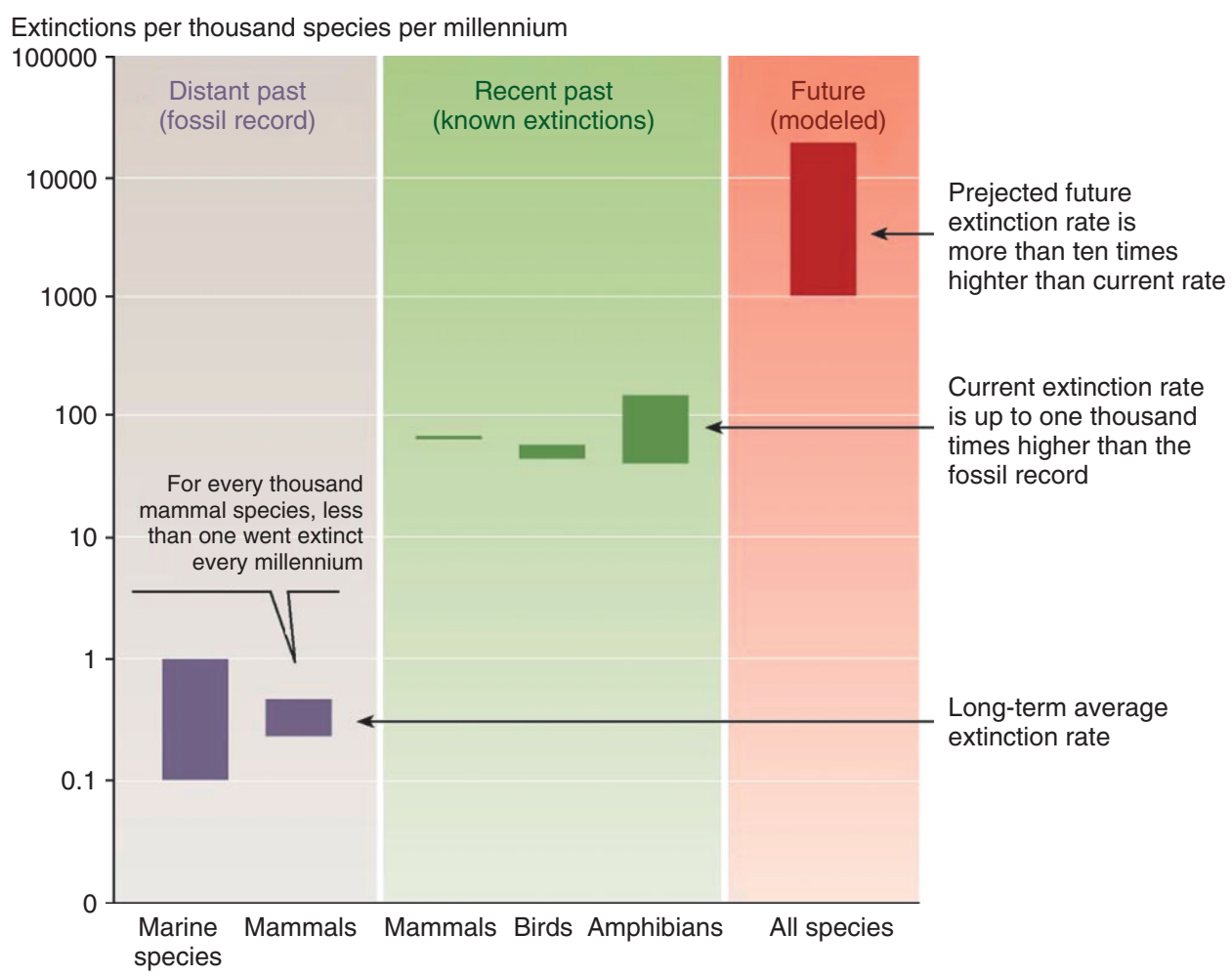

Source: Millennium Ecosystem Assesment
FIGURE 13 | Comparison of the extinction rate in the rate past and the rate projected for the 21st century with the long-term background rate of species loss estimated from the fossil record (Reprinted with permission from Ref 76 . Copyright 2005 Island Press). 
300,000 humans born every day is approximately equal to the total population of great apes on the planet.

Biological diversity is more than an aesthetic ecosystem service; it is also important in the functioning of ecosystems and, ultimately, in the functioning of the Earth System as a whole. Some research has now been carried out to examine the relationship between diversity and functioning, but this work is largely limited to simple ecosystems, primarily temperate grasslands. Nevertheless, at least two major roles of diversity can be defined: (1) modulating the primary production of ecosystems and thus directly influencing the carbon cycle; and (2) acting as an 'insurance policy' via functional redundancy, whereby the loss of one species does not affect the functioning of an ecosystem because another species can assume its functional role.

The overall results of experiments on temperate grasslands, in which the number and nature of the species comprising the ecosystem is experimentally manipulated, show that plant biomass increases with an increasing number of species. ${ }^{80}$ It is not clear whether this is due to the fact that more niches are filled with more species, thus accessing more resources, or whether more species simply increases the probability that a highly productive species will be found in the ecosystem. There is also some evidence for a diversity-functioning relationship in marine ecosystems, in this case related to nutrient turnover. ${ }^{81}$

The redundancy role is crucial for the functioning of the Earth System, as it provides ecosystems with a buffer against rapid changes in the abiotic environment. ${ }^{82}$ Thus, in general, more diverse ecosystems are likely to be more resilient to change than simpler systems, although definitive experimental or observational evidence for this relationship is not yet readily available. There is some circumstantial evidence from experiments that show a decrease in the variability of ecosystem processes with an increasing number of species. ${ }^{80}$

Scaling up the results from these very smallscale experiments to the planet as a whole is very difficult. Perhaps the only way to gain some insights into the implications of a mass extinction event at the global scale is from the palaeo record. The Tertiary extinction of the dinosaurs and their replacement by mammals drove significant, permanent changes to the composition and functioning of the Earth's ecosystems. This hints at the importance of both aspects of the diversity-functioning relationship, and suggests that a mass extinction may even lead to abrupt and largely irreversible consequences for Earth's environment.

\section{CLIMATE CHANGE IN THE CONTEXT OF THE EARTH SYSTEM}

Trends in the behavior of the climate system are undoubtedly the most intensively studied aspect of Earth System science. These trends are largely covered elsewhere (see WILEY Interdisciplinary Reviews under the headings 'Paleoclimates and Current Trends' and 'Climate Models and Modeling') and have been summarized most recently in the Fourth Assessment Report of the Intergovernmental Panel on Climate Change. ${ }^{8}$ The main findings are:

1. Warming of the climate system is unequivocal, as is now evident from observations of increases in global average air and ocean temperatures, widespread melting of snow and ice, and rising global average sea level.

2. At continental, regional, and ocean basin scales, numerous long-term changes in climate have been observed. These include changes in arctic temperatures and ice, widespread changes in precipitation amounts, ocean salinity, wind patterns and aspects of extreme weather including droughts, heavy precipitation, heat waves, and the intensity of tropical cyclones.

3. Paleoclimate information supports the interpretation that the warmth of the last half-century is unusual in at least the previous 1300 years. The last time polar regions were significantly warmer than present for an extended period (about 125,000 years ago), reductions in polar ice volume led to 4-6 $\mathrm{m}$ of sea level rise.

4. Most of the observed increase in global average temperatures since the mid-20th century is very likely ${ }^{\mathrm{a}}$ due to the observed increase in anthropogenic greenhouse gas concentrations.... Discernible human influences now extend to other aspects of climate, including ocean warming, continental-average temperatures, temperature extremes, and wind patterns.

5. Continued greenhouse gas emissions at or above current rates would cause further warming and induce many changes in the global climate system during the 21 st century that would very likely be larger than those observed during the 20th century.

In this overview, the focus is on trends in the climate system in the context of the behavior of the Earth System as a whole, or in other aspects of the Earth System. Climate change itself is an indirect consequence of changes in many parts of the Earth 
System. The carbon cycle is the most well-known of these (see Section on Carbon Cycle), but changes in the nitrogen cycle, the Earth's land cover and the cryosphere, for example, all affect the climate directly through changes in the radiative balance of the planet, either through changes in atmospheric composition (greenhouse gases and aerosols) or through the albedo (reflectivity) of the Earth's surface. Interactions among biogeochemical cycles indirectly affect trends in the climate system; for example, the productivity of land ecosystems, and hence their role in modulating atmospheric $\mathrm{CO}_{2}$ concentration, is influenced by interactions with the nitrogen and phosphorus cycles and with the hydrological cycle.

The impacts of a changing climate are often viewed from the perspective of human societies and the ecosystem services on which we depend (see also WILEY Interdisciplinary Review 'Assessing Impacts of Climate Change'), but they also affect the functioning of other aspects of the Earth System. For example, the changing heat balance in the upper ocean can change ocean circulation, thereby affecting upwelling processes in some coastal seas and the consequent provision of nutrients for marine ecosystems. A warming climate is also impacting strongly on the behavior of terrestrial ecosystems; effects include the advancement of treelines toward higher latitudes and altitudes; the increased productivity of many systems under a warmer, wetter climate; but also the increase in wildfire in many parts of the world. The overall, integrated effect of these impacts on the role of terrestrial ecosystems in the functioning of the Earth System is difficult to determine.

An alternative to the processes-impactsfeedbacks approach described above is to view climate change from a complex systems perspective. In this approach, climate is one emergent property of many interacting processes in the Earth System, and changes in climate can then be viewed as transitions between states of the Earth System, or important subsystems of the Earth System. For example, during the late Quaternary, climate can be considered as oscillating with a regular periodicity between two fundamental states-glacial and interglacial. ${ }^{5}$

A recent analysis of 'tipping elements' in the Earth System has examined a number of subsystems that could exhibit threshold-type behavior (change to another state) this century under forcing by anthropogenic climate change. ${ }^{83}$ Threshold behavior occurs when a small change in a forcing factor triggers a unexpectedly large and rapid response (Figure 14). Threshold behavior may also be associated with irreversible as well as abrupt changes.

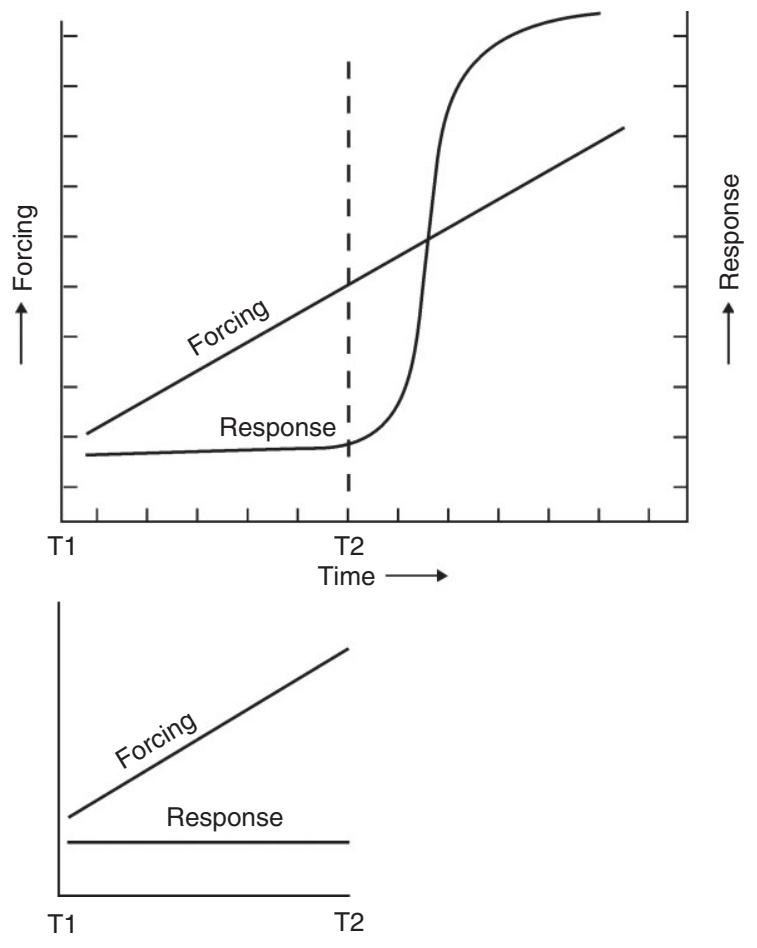

FI GURE 14 | Thresholds and abrupt changes. Many processes within the Earth System are well-buffered and appear to be unresponsive to a forcing factor (e.g., between $\mathrm{T} 1$ and $\mathrm{T} 2$ in lower figure) until a threshold is crossed and then a major change occurs abruptly (Reprinted with permission from Ref 6. Copyright 2004 Springer-Verlag).

An often-quoted example of threshold-abrupt change behavior is the potential rapid loss of the Amazon rainforest later this century. The concern is that land-cover change, in the form of conversion of rainforest into cropland or grazing systems, may reach a critical level where an additional small amount of clearing could drive a rapid, irreversible change into a semi-arid savanna. ${ }^{84,85}$ The process that could tip the rainforest system would be a reduction in the transpiration feedback from the forest, leading to a drop in rainfall, a drying of the remaining forests, and a consequent increase in vulnerability to large-scale fires.

An example of a tipping element that exhibits irreversible (on time scales of importance to humans) behavior is the potential loss of the Greenland ice sheet. It is conceivable that sometime this century regional temperatures in the northern high latitudes would rise enough to cause a threshold to be crossed, leading to the eventual loss of the ice sheet and a consequent sea level rise of about $7 \mathrm{~m} .{ }^{86}$ The time for the ice sheet to be completely lost would likely be many centuries, however.

There is also concern about the future behavior of the West Antarctic Ice Sheet (WAIS), which may be even more vulnerable than the Greenland Ice Sheet. ${ }^{87}$ 
Much of the WAIS is grounded below sea level; rising sea temperature can cause melting at the base of the ice sheet and possibly destabilize a large fraction of the ice sheet in a short period of time. The WAIS has apparently experienced rapid periods of retreat and advance during the past climatic changes, ${ }^{88}$ and appears to have collapsed during the Pliocene with temperature about $3^{\circ} \mathrm{C}$ above the present. ${ }^{89}$

These examples of abrupt or irreversible changes in important subsystems of the Earth System probably would not qualify as 'trends' in the normal sense, but would nevertheless be important changes in the functioning of the Earth System.

\section{THE ANTHROPOCENE}

The concept of the Anthropocene $e^{90,91}$ captures the theme of this review-that over the past 200 years the trends in Earth System behavior have, in many cases, been dominated by human activities. Although not yet formally accepted by the geological community as a new epoch for the planet, the Anthropocene has become widely used in the scientific community since its introduction in 2000 to recognize that human activities have now become so profound and pervasive that they rival, or exceed, the great forces of Nature in influencing the functioning of the Earth System.

Figure 15 describes visually many of the significant changes in the human enterprise that have occurred since the beginning of the Industrial Revolution. ${ }^{6}$ The individual graphs, which are global aggregates and mask significant regional differences, depict trajectories in demographics, economic activity, resource use, communication, transportation, and globalization. Population is a key underlying driver of change, but many other aspects of the human enterprise are changing more rapidly, especially communication and transport. In terms of the IPAT identity introduced in the section on Ultimate Human Drivers, the A (affluence) and T (technology) terms are becoming increasingly important as drivers of change to the global environment; that is, the consumption per capita is now rising more quickly than the population itself.

One of the most remarkable features of Figure 15 is the sharp change in slope of all of the curves at the year 1950. Indeed, in some cases (e.g., transport by motor vehicle and international tourism), the activity was virtually non-existent before 1950 . This feature of the trajectories of the human enterprise has prompted a more detailed analysis that defines the stages of the Anthropocene, beginning with the advent of the Industrial Revolution around $1800 .{ }^{92}$ The profound changes that occurred after the end of the
Second World War mark Stage 2 of the Anthropocene, sometimes called the Great Acceleration. ${ }^{93}$ There is not one single trigger for the emergence of the Great Acceleration, but rather the phenomenon has been driven by a complex set of interacting factors, including extensive changes in global political and economic institutions, such as the establishment of the Bretton Woods institutions; the emergence of a world economy based on capitalist, neo-liberal principles; the emergence of armies of scientists and technologists from the war effort; the rapid increase in financial and information flows via the globalization process; and the 'growth imperative' as an underlying driver of economic and societal development. ${ }^{92-94}$

Figure 16 shows the implications for key aspects of Earth System structure and functioning of the changes in the human enterprise shown in Figure 15. The rapid acceleration in the human enterprise after 1950 is clearly visible in the trajectories of changes in the Earth System over the past half-century, although there is not a simple one-to-one correspondence due to buffering and lag effects in Earth System processes. Nevertheless, it is clear that the Earth System has moved well outside the envelope of natural variability that has characterized its structure and functioning during the previous 10,000 years of the Holocene. A recent synthesis of research on Earth System dynamics concluded that ' ... the Earth is currently operating in a no-analogue state. In terms of key environmental parameters, the Earth System has recently moved well outside the range of natural variability exhibited over at least the last half million years. The nature of changes now occurring simultaneously in the Earth System, their magnitudes and rates of change, are unprecedented'. ${ }^{6}$

The Earth is now in the transition between Stages 2 and 3 of the Anthropocene. The transition is characterized by the fact that humans are now becoming aware of their influence on the environment at the global scale, and of the need to somehow manage their relationship with the rest of nature. International instruments such as the United Nations Framework Convention on Climate Change (UNFCCC) and the Convention on Biological Diversity (CBD) are first tentative steps toward building an international system of Earth System governance, although much remains to be done. Approaches to managing the relationship between human societies and the global environment vary widely, from sustainability approaches that emphasize living within planetary boundaries $^{95}$ to manipulating the Earth System itself through geo-engineering approaches. ${ }^{92}$ Whatever unfolds through the rest of the 21st century, it seems likely that Homo sapiens will continue to be a 

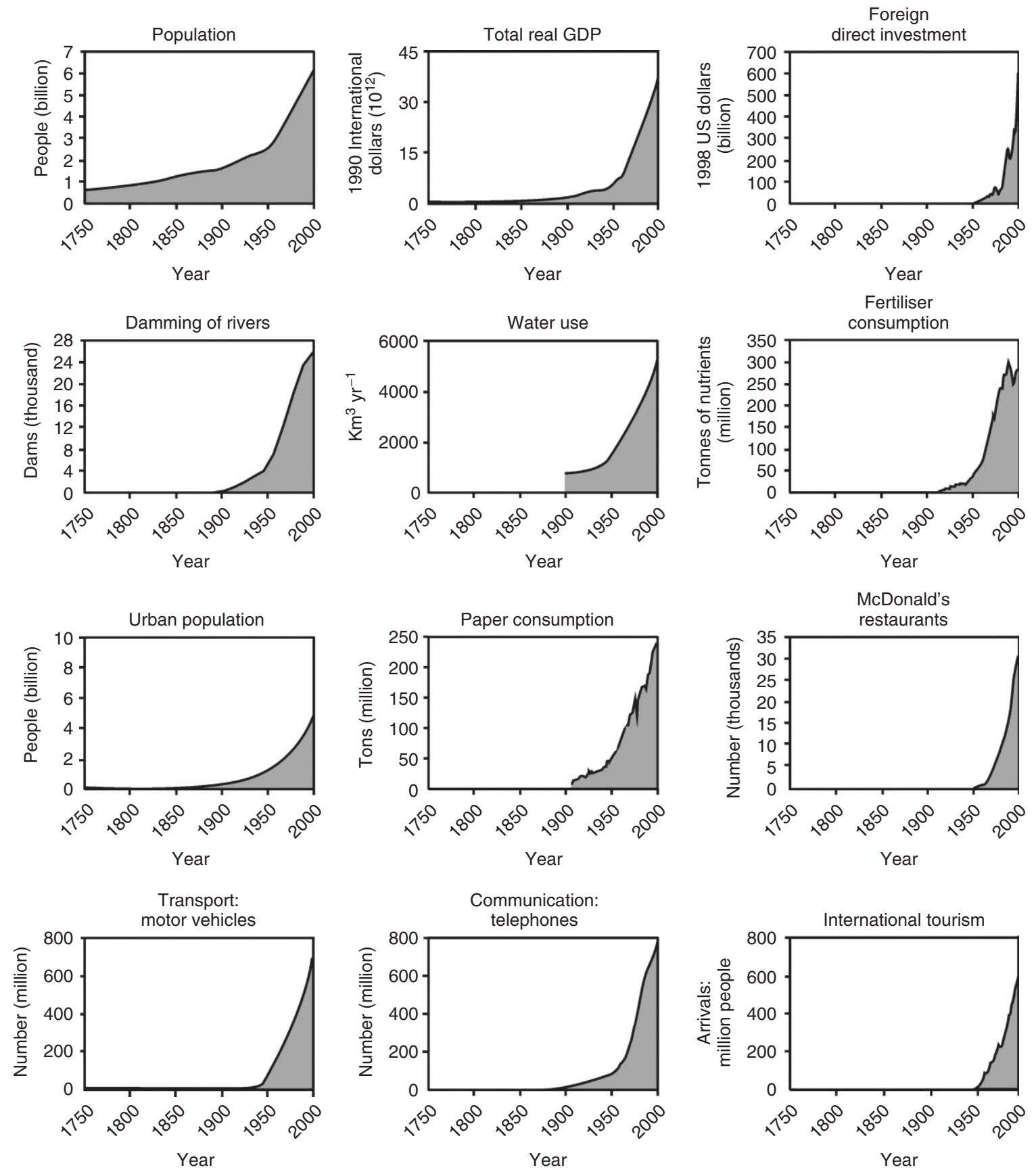

FIG URE 15 | The increasing rates of change in human activity since the beginning of the Industrial Revolution. Sharp changes in the slope of the curves occur around the 1950s in each case and illustrate how the past 50 years have been a period of dramatic and unprecedented change in human history (see Ref 6, which includes references to the individual data sets).

significant driver of trends in Earth System behavior for centuries and millennia into the future.

\section{CONCLUSIONS}

This review has surveyed changes in the behavior of the Earth System over the past 200 years. Prior to the advent of the Industrial Revolution about 200 years ago, observed Earth System behavior over the past 10,000 years was constrained within relatively welldefined patterns of variability. However, over recent times, the human imprint on the structure of the Earth System - the land, the ocean, the atmosphere, and the cryosphere-is profound, and has led to significant changes in the behavior of many biogeochemical cycles as well as the physical climate system. Thus, human 
(a)

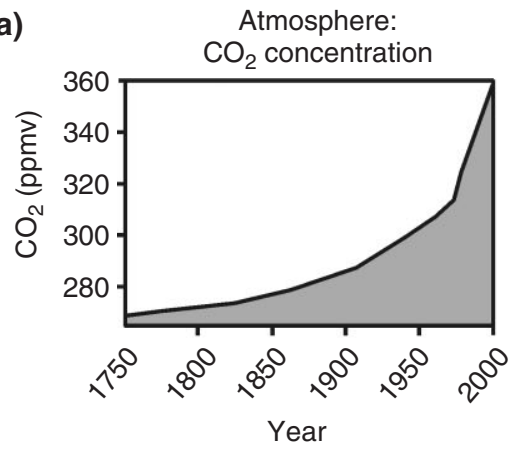

(d)

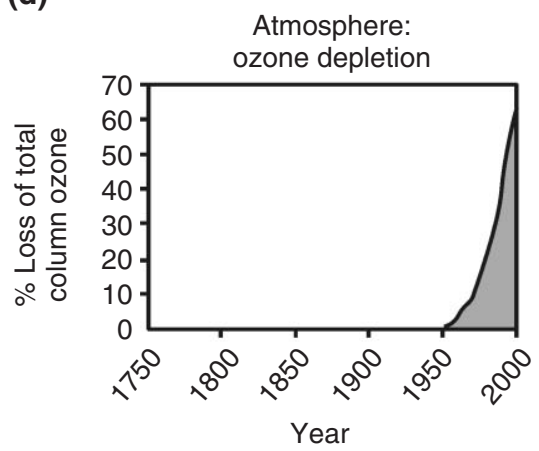

(g)

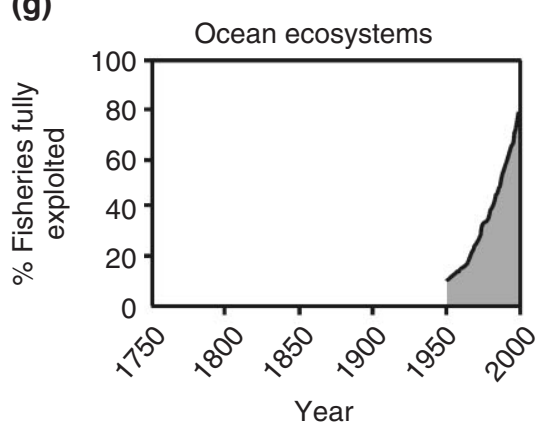

(j)

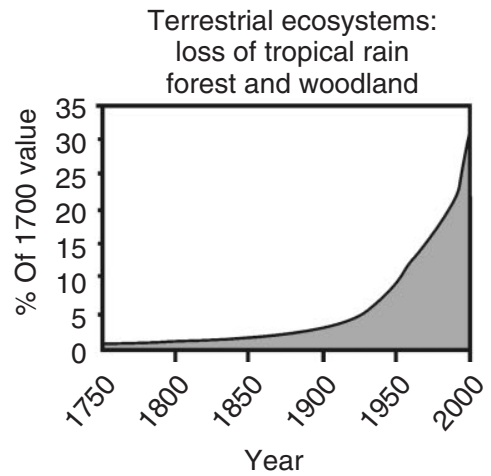

(b)

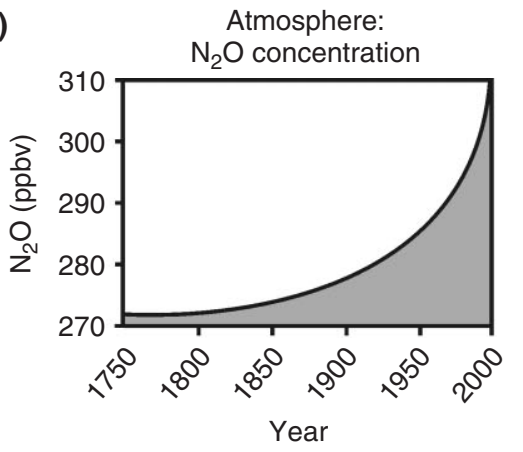

(e)

Climate: northern hemisphere average

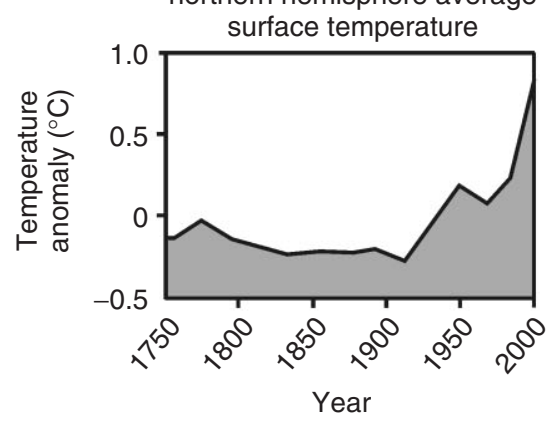

(h)

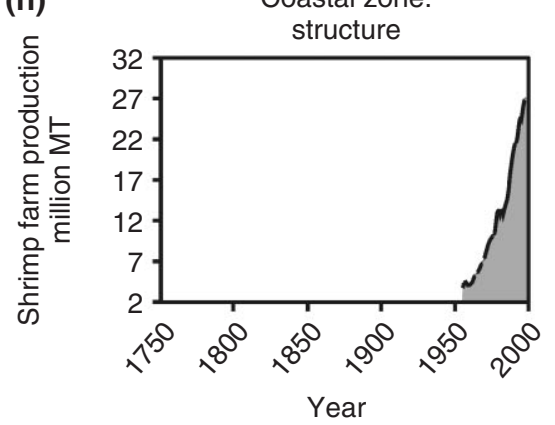

(k)

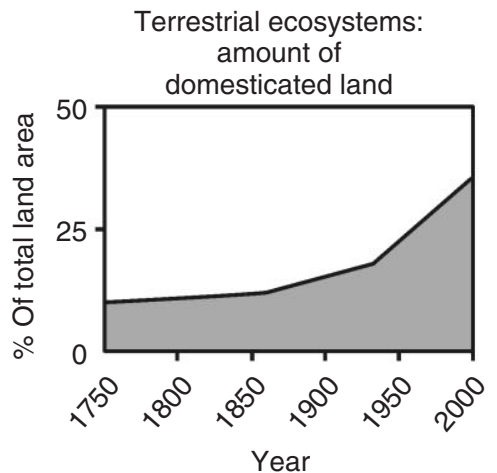

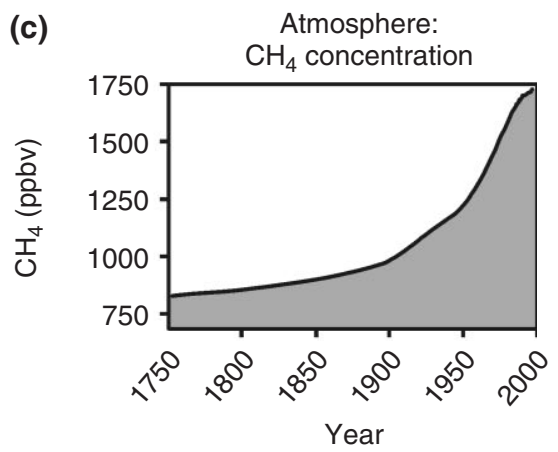

(f)

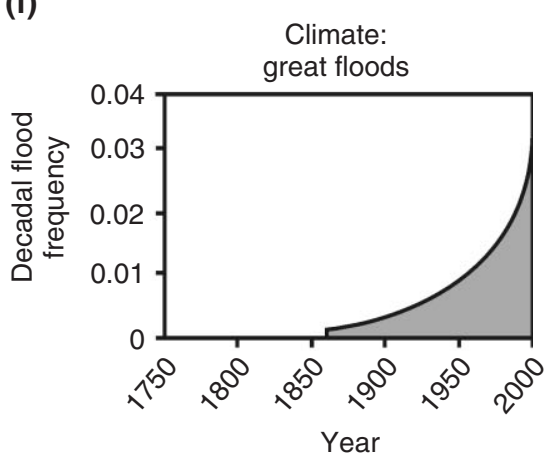

(i)

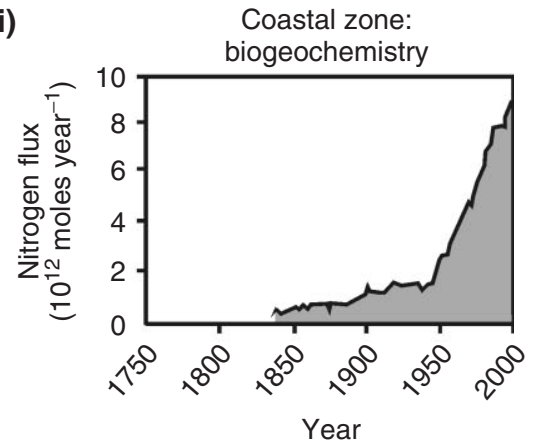

(I)

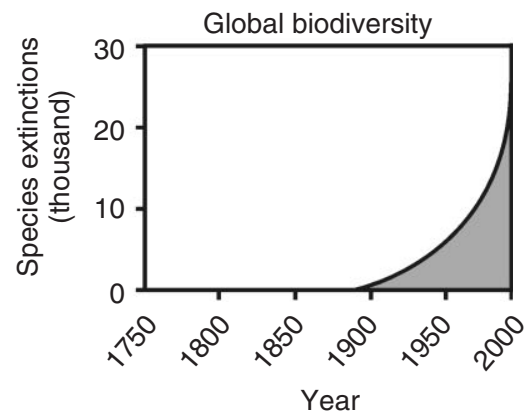

FIG URE 16 | Global-scale changes in the Earth System as a result of the dramatic increase in human activity shown in Figure 15 (see Ref 6, which includes references to the individual data sets). 
activities now dominate the observed changes in the structure and functioning of the Earth System.

It is likely that human activities will be even more important over the next few centuries or millennia in influencing the behavior of the Earth System. Understanding the past is therefore essential, both to comprehend the full implications of the human modification of Earth System functioning and to test model-based simulations of future change.

\section{NOTE}

${ }^{a}$ Very likely is defined by the IPCC to mean $>90 \%$ probability of the occurrence or outcome.

\section{REFERENCES}

1. Walker M, Johnsen S, Rasmussen SO, Popp T, Steffensen J-P, et al. Formal definition and dating of the GSSP (Global Stratotype Section and Point) for the base of the Holocene using the Greenland NGRIP ice core and selected auxiliary records. Journal of Quaternary Science 2009, 24:3-17.

2. Oldfield F, Steffen W. The Earth System. In: Steffen W, Sanderson A, Tyson PD, Jäger J, Matson P, et al. (eds) Global Change and the Earth System: A Planet Under Pressure, The IGBP Book Series, Berlin, Heidelberg, New York: Springer-Verlag; 2004, 7.

3. EPICA Community Members. Eight glacial cycles from an Antarctic ice core. Nature 2004, 429:623-628.

4. Lüthi D, Le Floch M, Bereiter B, Blunier T, Barnola $\mathrm{J}-\mathrm{M}$, et al. High-resolution carbon dioxide concentration record $650,000-800,000$ years before present. Nature 2008, 453:379-382.

5. Petit JR, Jouzel J, Raynaud D, Barkov NI, Barnola $\mathrm{J}-\mathrm{M}$, et al. Climate and atmospheric history of the past 420,000 years from the Vostok ice core, Antarctica. Nature 1999, 399:429-436.

6. Steffen W, Sanderson A, Tyson PD, Jäger J, Matson P, et al. Global Change and the Earth System: A Planet Under Pressure. The IGBP Book Series, Berlin, Heidelberg, New York: Springer-Verlag; 2004, 336 pp.

7. Vitousek PM, Mooney HA, Lubchenco J, Melillo JM. Human domination of Earth's ecosystems. Science 1997, 277:494-499.

8. IPCC. Climate Change 2007: The Physical Science Basis. Contribution of Working Group I to the Fourth Assessment Report of the Intergovernmental Panel on Climate Change 2007. Solomon S, Qin D, Manning M, Chen Z, Marquis MC, Avery K, Tignor M, Miller HL (eds), Cambridge University Press.

9. Brown L, Flavin C, French H, Abramovitz JN, Dunn S, et al. State of the World 2001. New York: The Worldwatch Institute. Norton and Company; 2001.

10. Yudelman M, Ratta A, Nygaard D. Pest Management and Food Production: Looking to the Future. 2020 Vision, Food, Agriculture and the Environment. 1998. Discussion paper 25. International Food Policy Research Institute, Washington DC.
11. FAOSTAT Statistical Databases. 2002. Food and Agriculture Organization of the United Nations, Rome. Available at: http://www.apps.fao.org; (Accessed August 12, 2002).

12. FAO State of the World's Forest 2001. 2001. Food and Agriculture Organization of the United Nations, Rome. Available at: http://www.fao.org/forestry/fo/sofo/sofoe.stm; (Accessed August 12, 2002).

13. Matthews E, Payne R, Rohweder M, Murray S. Pilot Analysis of Global Ecosystem. Forest Ecosystems. Washington, DC: World Resources Institute. 2000. Available at: http://www.wri.org/wr2000; (Accessed August 12, 2002).

14. Brown C. Global Forest Products Outlook Study: Thematic Study on Plantations. Working Paper No. GFPOS/WP/03 (draft). Food and Agriculture Organization of the United Nations, Rome, 1999.

15. FAO Marine fisheries and the law of the sea: A decade of change. 1993, Food and Agricultural Organization of the United Nations, Fisheries Circular No.853, Rome.

16. FAO The state of world fisheries and aquaculture. 2000. Food and Agricultural Organization of the United Nations, Rome. Available at: http://www. fao.org/sof/sofia/index_en.htm; (Accessed April 30, 2002).

17. USGS U.S. Geological Survey World Petroleum Assessment 2000. U.S. Geological Survey World Energy Assessment Team, United States Geological Survey. 2000. Available at http://greenwood.cr.usgs.gov/ energy/WorldEnergy/DDS-60/; (Accessed April 2, 2002).

18. UNEP Global environmental outlook 2000. 2000. Clarke R (ed) United Nations Environment Programme.

19. Raskin P, Chadwick M, Jackson T, Leach G. The Sustainability Transition: Beyond Conventional Development. Polestar Series 1. Stockholm: Stockholm Environment Institute; 1996.

20. Ehrlich PR, Holdren JP. Impact of population growth. Science 1971, 171:1212-1217.

21. Holdren JP, Ehrlich PR. Human population and the global environment. American Scientist 1974, 62:282-292. 
22. Laureti E. Fish and Fishery Products: World and Apparent Consumption Statistics based on Food Balance Sheets. Rome: Food and Agriculture Organization of the United Nations; 1999 (FAO Fisheries Circular No. 821, Revision 5).

23. Geist HJ, Lambin EF. Proximate causes and underlying forces of tropical deforestation. BioScience 2002, 52:143-150.

24. Ramankutty N, Evan AT, Monfreda C, Foley JA Farming the planet: 1. Geographic distribution of global agricultural lands in the year 2000. Global Biogeochem. Cycles 2008, 22:GB1003. DOI:10.1029/2007GB002952.

25. FAO The state of the worlds forest, 1999. 1999. Food and Agricultural Organization of the United Nations, Rome.

26. Achard F, Eva HD, Mayaux P, Stibig HJ, Belward A. Improved estimates of net carbon emissions from land cover change in the tropics for the 1990s. Global Biogeochemical Cycles 2004, 18. DOI:10.1029/2003GBC002142.

27. Klein Goldewijk K, Battjes JJ. One Hundred Year Database for Integrated Environmental Assessments. Bilthoven, Netherlands: National Institute for Public Health and the Environment (RIVM); 1997.

28. Vitousek PM, Ehrlich PR, Ehrlich AH, Matson PA. Human appropriation of the products of photosynthesis. BioScience 1986, 36:368-373.

29. DeFries RS, Field CB, Fung I, Collatz GJ, Bounuoa L. Combing satellite data and biogeochemical models to estimate global effects on human-induced land cover change on carbon emissions and primary productivity. Global Biogeochemical Cycles 1999, 13:803-815.

30. Rojstaczer S, Sterling SM, Moore NJ. Human appropriation of photosynthesis products. Science 2001, 294:2549-2552.

31. Pauly D, Christensen V. Primary production required to sustain global fisheries. Nature 1995, 374:255-257.

32. Guinotte JM, Fabry VJ. Ocean acidification and its potential effects on marine ecosystems. Ann. New York Acad. Sci. 2008, 1134:320-342.

33. Riebesell U, Zondervan I, Rost B, Tortell PD, Zeebe $\mathrm{RE}$, et al. Reduced calcification of marine plankton in response to increased atmospheric $\mathrm{CO}_{2}$. Nature 2000, 407:364-367.

34. Hoegh-Guldberg O, Mumby PJ, Hooten AJ, Steneck RS, Greenfield P, et al. Coral reefs under rapid climate change and ocean acidification. Science 2007, 318:1737-1742.

35. LOICZ Coastal typology project of the IGBP/LOICZ project. 2002. Land-Ocean Interactions in the Coastal Zone International Project Office, Texel, Netherlands. Available at: http://www.nioz.nl/loicz/res.htm.
36. Kelleher G, Bleakley C, Wells S. A Global Representative System of Marine Protected Areas. Washington, DC: World Bank; 1995.Volume 1.

37. Naylor RL, Goldburg RJ, Mooney H, Beveridge M, Clay J, et al. Nature's subsidies to shrimp and salmon farming. Science 2000, 282:883-884.

38. WRI World resources: A guide to the global environment, The Urban Environment. 1996. World Resources Institute. Oxford University Press, Oxford and New York.

39. WRI World resources: People and ecosystems: The fraying web of life. 2000. World Resources Institute. Oxford University Press, Oxford and New York.

40. Fu C, Harasawa H, Kasyanov V, Kim J-W, Ojima $\mathrm{D}$, et al. Regional-global interactions in East Asia. In: Tyson P, Fuchs R, Fu C, Lebel L, Mitra AP, et al. (eds) Global-Regional Linkages in the Earth System. IGBP Global Change Series. Berlin Heidelberg New York: Springer-Verlag; 2002, 109-149.

41. Scholes MC, Matrai PA, Andreae MO, Smith KA, Manning MR. Biosphere-atmosphere interactions. In: Brasseur GP, Prinn RG, Pszenny AAP (eds) The Changing Atmosphere: An Integration and Synthesis of a Decade of Tropospheric Chemistry Research. The International Global Atmospheric Chemistry Project (IGAC). IGBP Global Change Series. Berlin Heidelberg, New York: Springer-Verlag; 2003, 19-71.

42. Brasseur GP, Artaxo P, Barrie LA, Delmas RJ, Galbally I, et al. An integrated view of the causes and impacts of atmospheric changes. In: Brasseur GP, Prinn RG, Pszenny AAP (eds) The Changing Atmosphere: An Integration and Synthesis of a Decade of Tropospheric Chemistry Research. The International Global Atmospheric Chemistry Project (IGAC). The IGBP Global Change Series. Berlin Heidelberg New York: Springer-Verlag; 2003, 207-271.

43. Heintzenberg J, Raes F, Schwartz SE, Ackermann I, Artaxo P, et al. Tropospheric aerosols. In: Brasseur GP, Prinn RG, Pszenny AAP (eds) The Changing Atmosphere: An Integration and Synthesis of a Decade of Tropospheric Chemistry Research. The International Global Atmospheric Chemistry Project (IGAC). IGBP Global Change Series. Berlin Heidelberg New York: Springer-Verlag; 2003, 125-156.

44. WMO. Scientific Assessment of Ozone Depletion: 1998. Global Ozone Research and Monitoring Project Report No. 44. Geneva, Switzerland: World Meteorological Organization; 1999, 732 pp.

45. Staehelin J, Schnadt Poberaj C. Long-term tropospheric ozone trends: a critical review. In: Brönnimann S, Luterbacher J, Ewan T, Diaz HF, Stolarski RS, et al. (eds) Climate Variability and Extremes During the Past 100 years. Advances in Global Change Research. Berlin Heidelberg, New York: Springer-Verlag; 2007, 271-282. 
46. UNEP/WMO. Scientific Assessment of Ozone Depletion. 2002. Prepared by the Scientific assessment panel of the Montreal Protocol on Substances that deplete the ozone hole. United Nations Environment Programme/World Meteorological Organization.

47. Etheridge DM, Steele LP, Langenfelds RL, Francey RJ, Barnola J-M, et al. Natural and anthropogenic changes in atmospheric $\mathrm{CO}_{2}$ over the last 1000 years from air in Antarctic ice and firn. Journal of Geophys. Res. 1996, 101:4115-4128.

48. Etheridge DM, Pearman GI, Fraser PJ. Changes in tropospheric methane between 1841 and 1978 from a high accumulation-rate Antarctic ice core. Tellus 1992, 44B:282-294.

49. Blunier T, Chappellaz J, Schwander J, Barnola J-M, Desperts T, et al. Atmospheric methane record from a Greenland ice core over the last 1000 years. J. Geophys. Res 1993, 20:2219-2222.

50. Machida T, Nakazawa T, Fujii Y, Aoki S, Watanabe O. Increase in the atmospheric nitrous oxide concentration during the last 250 years. Geophys. Res. Lett. 1995, 22:2921-2924.

51. Rignot E, Kanagaratnam P. Changes in the velocity structure of the Greenland Ice Sheet. Science 2006, 311:986-990.

52. Cazenave A. How fast are the ice sheets melting? Science 2006, 314:1250-1252.

53. Gordon LJ, Steffen W, Jönsson BF, Folke C, Falkenmark M, et al. Human modification of global water vapor flows from the land surface. Proc Natl Acad Sci USA 2005, 102:7612-7617.

54. Vörösmarty CJ, Meybeck M, Fekete B, Sharma K, Green P, et al. Anthropogenic sediment retention: major global-scale impact from the population of registered impoundments. Global Planet. Change 2003, 39:169-190.

55. Dynesius M, Nilsson C. Fragmentation and flow regulation of river systems in the Northern third of the world. Science 1994, 266:753-762.

56. Molden D, Frenken K, Barker R, de Fraiture C, Mati B, et al. Trends in water and agricultural development. In: Molden D (ed) Water for Food, Water for Life: A Comprehensive Assessment of Water Management in Agriculture. London, and IWMI, Colombo: Earthscan; 2007, 57-89.

57. Vörösmarty CJ, Sharma K, Fekete B, Copeland AH, Holden $\mathrm{J}$, et al. The storage and aging of continental runoff in large reservoir systems of the world. Ambio 1997, 26:210-219.

58. Prentice IC, Farquhar GD, Fasham MJR, Goulden ML, Heimann M, et al. The carbon cycle and atmospheric carbon dioxide. In: Houghton JT, Ding Y, Griggs DJ, Noguer M, van der Linden PJ, et al. (eds) Climate Change 2001: The Scientific Basis. Contribution of Working Group I to the Third Assessment Report of the Intergovernmental Panel on Climate Change. Cambridge University Press, Cambridge, U.K. and New York 2001, 185-237.

59. Canadell JG, Le Quéré C, Raupach MR, Field CR, Buitenhuis E, et al. Contributions to accelerating atmospheric $\mathrm{CO}_{2}$ growth from economic activity, carbon intensity, and efficiency of natural sinks. Proc Natl Acad Sci USA 2007, 104:18866-18870.

60. Global Carbon Project. Carbon Budget and Trends 2007. 2008. http://www.globalcarbonproject.org, (Accessed September 26, 2008).

61. Le Quéré C, Rodenbeck C, Buitenhuis ET, Conway TJ, Langenfelds R, et al. Saturation of the Southern Ocean $\mathrm{CO}_{2}$ sink due to recent climate change. Science 2007, 316:1735-1738.

62. IPCC Special Report on Emissions Scenarios. 2000. $\mathrm{N}$ Nakicenovic and R Swart (eds). Intergovernmental Panel on Climate Change, Cambridge University Press 570 pp.

63. Friedlingstein P, Cox P, Betts R, Bopp L, von Bloh W, et al. Climate-carbon cycle feedback analysis: results from the C4MIP model intercomparison. J. Climate 2006, 19:3337-3353.

64. Tarnocai C, Canadell JG, Schuur EAG, Kuhry P, Mazhitova G, et al. Soil organic carbon pools in the northern circumpolar permafrost region. Global Biogeochemical Cycles 2009, 23. DOI: 10.1029/2008 GB003327. (in press).

65. Schurr EAG, Bockheim J, Canadell JG, Euskirchen E, Field $\mathrm{CB}$, et al. Vulnerability of permafrost carbon to climate change: Implications for the global carbon cycle. Bioscience 2008, 58:701-714.

66. Falkowski P, Scholes RJ, Boyle E, Canadell J, Canfield D, et al. The global carbon cycle: a test of knowledge of Earth as a system. Science 2000, 290:291-296.

67. Keeling CD, Whorf TP. Atmospheric $\mathrm{CO}_{2}$ Records from Sites in the SIO Air Sampling Network. Trends: A Compendium of Data on Global Change. Oak Ridge, TN: Carbon Dioxide Information Analysis Center, Oak Ridge National Laboratory, US Department of Energy, 2000.

68. Galloway JN, Cowling EB. Reactive nitrogen and the world: two hundred years of change. Ambio 2002, 31:64-71.

69. Gruber N, Galloway JN. An earth system perspective of the global nitrogen cycle. Nature 2008, 451:293-296.

70. Mackenzie FT, Ver LM, Lerman A. Century-scale nitrogen and phosphorus controls of the carbon cycle. Chemical Geology 2002, 190:13-32.

71. Jahnke RA. The phosphorus cycle. In: Jacobson MC, Charlson RJ, Rodhe H, Orians GH (eds) Earth System Science: From Biogeochemical Cycles to Global Change. London: Academic Press; 2000, 360-376.

72. Reeburgh WS. Figures summarizing the global cycles of biogeochemically important elements. Bull. 
Ecol. Soc. Am. 1997, 78:260-267. Available at: http://www.ess.uci.edu/ reeburgh (Accessed October 23, 2002).

73. Charlson RJ, Anderson TL, McDuff RE. The sulfur cycle. In: Jacobson MC, Charlson RJ, Rodhe H, Orians GH (eds) Earth System Science: From Biogeochemical Cycles to Global Change. London: Academic Press; 2000, 343-359.

74. Diaz S, Tilman D, Fargione J, Chapin FS III, Dirzo R, et al. Biodiversity regulation of ecosystem services. In: Hassan H, Scholes R, Ash N. Ecosystems and Human Well-Being: Current State and Trends. Washington DC: Island Press; 2005, 297-329.

75. Pimm SL, Russell GJ, Gittleman JL, Brooks TM. The future of biodiversity. Science 1995, 269:347-350.

76. MEA (Millennium Ecosystem Assessment) Ecosystems and Human Well-being: Synthesis. 2005. Island Press, Washington, DC, USA.

77. Chapin FSIII, Zaveleta ES, Eviner VT, Naylor RL, Vitousek PM, et al. Consequences of changing biotic diversity. Nature 2000, 405:234-242.

78. Loh J, Wackernagel M. Living Planet Report 2004. Gland, Switzerland: WWF International; 2004.

79. Lindenmayer DB. On Borrowed Time: Australia's Environmental Crisis and What we Must do about it. Melbourne: CSIRO Publishing and Penguin; 2007.

80. Loreau M, Naeem S, Inchausti P, Bengtsson J, Grime $\mathrm{JP}$, et al. Biodiversity and ecosystem functioning: current knowledge and future challenges. Science 2001, 294:804-808.

81. Emmerson MC, Solan M, Emes C, Paterson DM, Raffaelli D. Consistent patterns and the idiosyncratic effects of biodiversity in marine ecosystems. Nature 2001, 411:73-77.

82. Yachi S, Loreau M. Biodiversity and ecosystem productivity in a fluctuating environment: The insurance hypothesis. Proc. Natl. Acad. Sci. (USA) 1999, 96:1463-1468.

83. Lenton TM, Held H, Kriegler E, Hall JW, Lucht W, et al. Tipping elements in the Earth's climate system. Proc Natl Acad Sci (USA) 2008, 105:1786-1793.
84. Oyama MD, Nobre CA. A new climate-vegetation equilibrium state for tropical South America. Geophys. Res. Lett. 2003, 30. DOI:10.1029/2003GL018600.

85. Foley JA, Asner GP, Costa MH, Coe MT, DeFries R, et al. Amazonian revealed: forest degradation and loss of ecosystem goods and services in the Amazon Basin. Frontiers Ecol. Environ. 2007, 5:25-32.

86. Gregory JM, Huybrechts P. Ice-sheet contributions to future sea-level change. Philos. Trans. R. Soc. London Ser. A. 2006, 364:1709-1731.

87. Mercer JH. West Antarctic ice sheet and $\mathrm{CO}_{2}$ greenhouse effect: a threat of disaster. Nature 1978, 271:321-325.

88. Pollard D, DeConto RM. Modelling West Antarctic ice sheet growth and collapse through the past five million years. Nature 2009, 458:329-332.

89. Naish T, Powell R, Levy R, Wilson G, Scherer R, et al. Obliquity-paced Pliocene West Antarctic ice sheet oscillations. Nature 2009, 458:322-328.

90. Crutzen PJ, Stoermer EF. The anthropocene. IGBP Newsletter 2000, 41:12.

91. Crutzen PJ. Geology of mankind: the anthropocene. Nature 2002, 415:23.

92. Steffen W, Crutzen PJ, McNeill JR. The anthropocene: are humans now overwhelming the great forces of nature? AMBIO J 2007, 36:614-621.

93. Hibbard KA, Crutzen PJ, Lambin EF, Liverman D, Mantua NJ, et al. Decadal interactions of humans and the environment. In: Costanza R, Graumlich L, Steffen $\mathrm{W}$ (eds) Integrated History and Future of People on Earth. Dahlem Workshop Report 96, Cambridge, MA, USA MIT Press; 2006, 341-375.

94. McNeill JR. Something New Under the Sun. New York, London: W.W. Norton; 2001, 416 pp.

95. Rockström J, Steffen W, Noone K, Persson Å, Chapin S, et al. Planetary boundaries: exploring the safe operating space for humanity in the Anthropocene. Nature 2009, 461:472-475. 